\title{
Numerical study of tracers transport by a mesoscale convective system over West Africa
}

\author{
C. Barthe ${ }^{1}$, C. Mari ${ }^{2}$, J.-P. Chaboureau ${ }^{2}$, P. Tulet ${ }^{1,3}$, F. Roux ${ }^{2}$, and J.-P. Pinty ${ }^{2}$ \\ ${ }^{1}$ Laboratoire de l'Atmosphère et des Cyclones, UMR8105, CNRS - Université de la Réunion and Météo-France, Saint-Denis, \\ La Réunion, France \\ ${ }^{2}$ Laboratoire d'Aérologie, UMR5560, CNRS - Université de Toulouse, Toulouse, France \\ ${ }^{3}$ CNRM-GAME, URA1357, CNRS - Meteo-France, Toulouse, France
}

Received: 14 January 2011 - Revised: 21 March 2011 - Accepted: 27 April 2011 - Published: 3 May 2011

\begin{abstract}
A three-dimensional cloud-resolving model is used to investigate the vertical transport from the lower to the upper troposphere in a mesoscale convective system (MCS) that occurred over Niger on 15 August 2004. The redistribution of five passive tracers initially confined in horizontally homogeneous layers is analyzed. The monsoon layer tracer $(0-1.5 \mathrm{~km})$ is the most efficiently transported in the upper troposphere with concentrations 3 to 4 times higher than the other tracers in the anvil. On the contrary the African Easterly Jet tracer $(\sim 3 \mathrm{~km})$ has the lowest contribution above $5 \mathrm{~km}$. The vertical profiles of the mid-troposphere tracers $(4.5-10 \mathrm{~km})$ in the MCS exhibit two peaks: one in their initial layers, and the second one at $13-14 \mathrm{~km}$ altitude, underlying the importance of mid-tropospheric air in feeding the upper troposphere. Mid-tropospheric tracers also experience efficient transport by convective downdrafts with a consequent increase of their concentrations at the surface. The concentration of the upper troposphere-lower stratosphere tracer exhibits strong gradients at the edge of the cloud, meaning almost no entrainment of this tracer into the cloud. No downward transport from the upper troposphere is simulated below $5 \mathrm{~km}$. A proxy for lightning produced $\mathrm{NO}_{\mathrm{x}}$ is transported preferentially in the forward anvil in the upper troposphere. Additionally, lateral inflows significantly contribute to the updraft and downdraft airflows emphasizing the threedimensional structure of the West African MCSs.
\end{abstract}

Keywords. Meteorology and atmospheric dynamics (Convective processes)

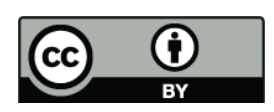

Correspondence to: C. Mari (celine.mari@aero.obs-mip.fr)

\section{Introduction}

It has long been recognized that deep convection in the tropics has a primary role in the global atmospheric circulation and energetics of the tropical atmosphere by extracting heat and momentum from the planetary boundary layer and redistributing it to the upper troposphere. In the 1980s, the pioneer works of Chatfield and Crutzen (1984) and Dickerson et al. (1987) have shown the potential role of deep tropical convection in the redistribution of trace gases from the lower to the upper troposphere. Since then, the role of deep convection as a venting process for trace gases and aerosols has been inferred from aircraft measurements, satellite observations and theoretical studies.

The impact of convection on atmospheric chemistry is complex. Sensitivity studies show potential for both the enhancement and diminution of ozone formation (Lelieveld and Crutzen, 1994; Thompson et al., 1997). Despite major improvements over the last two decades, further progress is still needed to parameterize deep convection in large-scale models (Randall et al., 2003; Arakawa, 2004; Barret et al., 2010; Ruti et al., 2011). As a major consequence, there is currently no consensus on the net effect of convective transport on the ozone budget in the upper troposphere. Based on analyses with global models, Lawrence et al. (2003), and Doherty et al. (2005) reached opposite conclusions that deep convection induces a net increase or decrease of ozone in the upper troposphere. Tost et al. (2006) pointed out the parameterization of deep convection as the main source of uncertainties in determining the sign and magnitude of ozone production in the global models. Based on a global model calculation, Prather and Jacob (1997) demonstrated that convective transport turns over the upper troposphere at rate $\left(0.08 \mathrm{day}^{-1}\right)$ comparable to photochemical processes controlling the abundance of $\mathrm{HO}_{\mathrm{x}}$ and $\mathrm{NO}_{\mathrm{x}}$. Using aircraft

Published by Copernicus Publications on behalf of the European Geosciences Union. 
measurements, Bertram et al. (2007) calculated a comparable convective turnover rate of $0.1-0.2 \mathrm{day}^{-1}$. Gettelman et al. (2002) showed that the convective turnover rate can vary drastically with the seasons and increases exponentially with altitude above the tropopause. Based on cloud brightness temperature analysis, the authors found turnover times shorter than a month at $11-12 \mathrm{~km}$ but exceeding a year at $16 \mathrm{~km}$ altitude. The rate at which air in the upper troposphere is replenished by convection has strong implications in terms of chemical equilibrium (Prather and Jacob, 1997) and oxidising capacity of the upper troposphere (Jaeglé et al., 1997; Collins et al., 1999).

Traditional parameterizations of convection represent only the ensemble mean of the small scales as a deterministic function of a large-scale flow, disregarding fluctuations arising at the small scales. Hence, small scale deviations from the ensemble mean can drive the large-scale variability, in particular in the presence of mesoscale organization (Neelin et al., 2008). This is the case in the Sahel region where deep convection frequently occurs in relatively large organized propagating systems known as mesoscale convective systems (MCS) (Chong et al., 1987; Laing and Fritsch, 1993; Redelsperger et al., 2002; Laing et al., 2008; Schwendike et al., 2010). During the West African Monsoon (WAM), MCSs are responsible for $70-80 \%$ of the rainfall in the wet tropics while they only represent $10-20 \%$ of the regional population of the convective systems (Mohr et al., 1999). MCSs have a well-defined structure which can be maintained while they propagate during a day or more. Most of these systems move faster than the surrounding air at all levels. They consist of a leading line of cumulonimbus clouds followed by a large region of more stratiform structure in the extensive precipitating trailing anvil cloud (Houze et al., 1989; Zipser, 1977; Redelsperger and Lafore, 1988; Lafore and Moncrieff, 1989). Within the framework of the African Monsoon Multidisplinary Analysis (AMMA) program (Redelsperger et al., 2006; Mari et al., 2010) several cloud resolving models succeeded in reproducing MCSs main features (e.g., Barthe et al., 2010; Tulet et al., 2010). On the other hand, an intercomparison exercise with six mesoscale models showed a wide spread in the rainfall rates across the simulations which was reduced only when sub-kilometric horizontal resolutions were considered (Guichard et al., 2010).

Over West Africa, between $5^{\circ} \mathrm{N}$ and $15^{\circ} \mathrm{N}$, ozone precursors are emitted from soils and vegetation, (Guenther et al., 1995; Serça et al., 1998; Jaeglé et al., 2004; Delon et al., 2008) and from urban areas (Aghedo et al., 2007; Minga et al., 2010). When on the MCSs path track, the emitted gases and aerosols are transported efficiently by convective updrafts in the upper troposphere where they modify the budget of ozone (Ancellet et al., 2009; Law et al., 2010), water vapor (Homan et al., 2010; Khaykin et al., 2009) and aerosols (Borrmann et al., 2010). Once in the upper troposphere, gases and aerosols are advected downwind of the African continent by the Tropical Easterly Jet (TEJ) and they can impact the ozone and aerosols budgets at continental and hemispheric scales (Prospero and Lamb, 2003; Saunois et al., 2008; Barret et al., 2008; Real et al., 2010). The concentration levels and geographical extension of these enriched air masses depend directly on the frequency and intensity of deep convection over West Africa.

A common approach when studying the net impact of deep convection is the use of passive tracers. At mid-latitude, Mullendore et al. (2005) performed three-dimensional (3-D) simulations of supercellular storms. Using tracers from different levels of the troposphere, they showed irreversible transport into the stratosphere of the tracer originating from the boundary layer, and weaker ascent of the tracer immediatly above the boundary layer on the flank of the updraft. Barth et al. (2007) used eight cloud-resolving models to simulate the 10 July 1996 STERAO storm observed near the ColoradoNebraska-Wyoming border. They showed that all the models reproduced an efficient transport of high concentration of $\mathrm{CO}$ originating from the boundary layer by updrafts, up to the cloud anvil, while both numerical simulations and in-situ observations revealed that $\mathrm{O}_{3}$ which concentration increases with altitude in the troposphere was depleted in the cloud. Over the tropics, Lafore and Moncrieff (1989) realized twodimensional simulations (2-D) of a West African squall line to investigate the organization and interaction between the convective and the stratiform regions. Three tracers were introduced in the lowest $6 \mathrm{~km}$ where most of the inflow originates. They showed that, depending on the vertical profile of the zonal wind and in particular on the intensity of the African Easterly Jet (AEJ), the MCS can be fed mainly by the front inflow or by both the front and rear inflows. Yasunaga et al. (2004) performed 2-D simulations at 1-km horizontal resolution of convection to study the detrainment of boundary layer air mass from convective systems over tropical oceans. They detected two peaks of detrainment at 600 and $200 \mathrm{hPa}$, the latter being the height of the most intense clouds.

The objective of the paper is to provide a numerical description of the transport of air masses into a typical West African MCS, that is a squall line, never investigated so far in three dimensions. To achieve this goal, the transport of idealized passive tracers by a propagating organized MCS over West Africa is simulated with a 3-D high resolution cloudresolving model. A MCS observed over West Africa during the summer 2004 serves as a real cloud for the idealized numerical experiment. Passive tracers were followed so as to deduce an integrated view of entrainment and detrainment pathways of air masses as a function of their initial vertical distribution. A particular attention was paid on the contrasted signature of transport in the convection and stratiform regions of the cloud system. The paper is structured as follows. Section 2 presents the model set-up. Section 3 gives an overview of the MCS and its environmental conditions from observations and simulation. Section 4 shows the resulting tracers transport, and Sect. 5 concludes the paper. 


\section{Model description}

The online-coupled model used in this study is the Meso-NH model (Lafore et al., 1998). A full description of the model capabilities is available on http://mesonh.aero.obs-mip.fr/.

\subsection{Numerical framework}

The case study was simulated with three two-way nested models with a horizontal grid spacing of 40,10 and $2.5 \mathrm{~km}$, respectively. The vertical grid has 90 vertical levels up to $31 \mathrm{~km}$ with grid spacings from $60 \mathrm{~m}$ (bottom) up to $400 \mathrm{~m}$ (model top). A sponge layer was applied from 18 to $31 \mathrm{~km}$ in order to dampen the upward-propagating gravity waves generated by the convection. The outer domain covered the West African region with an area of about $6000 \mathrm{~km} \times 4320 \mathrm{~km}$. The location of the domains is shown in Fig. 1a. The time step was 40,10 and $2 \mathrm{~s}$, respectively. The simulation was integrated from 00:00 UTC 15 August 2004 to 00:00 UTC 16 August 2004. The initial and lateral boundary conditions were obtained from European Center for Medium-Range Weather Forecast (ECMWF) analyses.

The physics of the model included the prognostic calculation of turbulence following Bougeault and Lacarrère (1989). A convection scheme based on mass-flux calculations was used for the two outer models at 40 and $10 \mathrm{~km}$ (Bechtold et al., 2001). For the inner grid $(2.5 \mathrm{~km})$, convection was explicitly resolved. Mixed-phase microphysics (Pinty and Jabouille, 1998) and subgrid cloudiness (Chaboureau and Bechtold, 2005) were available for these simulations. The surface fluxes were provided by the ISBA (Interaction among Soil-Biosphere-Atmosphere) model (Noilhan and Planton, 1989) for the natural patches and TEB (Town Energy Balance) model (Masson, 2000) for the urbanized patches. The radiative scheme was the one used at ECMWF (Gregory et al., 2000). Synthetic brightness temperatures (BT) corresponding to the Meteosat Second Generation (MSG) observations in the infrared channels were computed offline using the Radiative Transfer for Tiros Operational Vertical Sounder (RTTOV) code version 8.7 (Saunders et al., 2005), and compared against observations following Chaboureau et al. $(2000,2002)$.

\subsection{Tracers initialization}

The major goal of this work is to quantify the mass transport from the lower to the upper troposphere produced by a MCS over West Africa. For this purpose, it is convenient, following the work of Lafore and Moncrieff (1989), Scala et al. (1990), Lu et al. (2000), Yasunaga et al. (2004) and Mullendore et al. (2005) to describe the redistribution of passive tracers that were initially confined within horizontally homogeneous layers. Each tracer was initialized with a mixing ratio of $1 \mathrm{nmol} \mathrm{mol}^{-1}$ throughout its source layer and zero outside that layer. The tracers were considered to be insol-

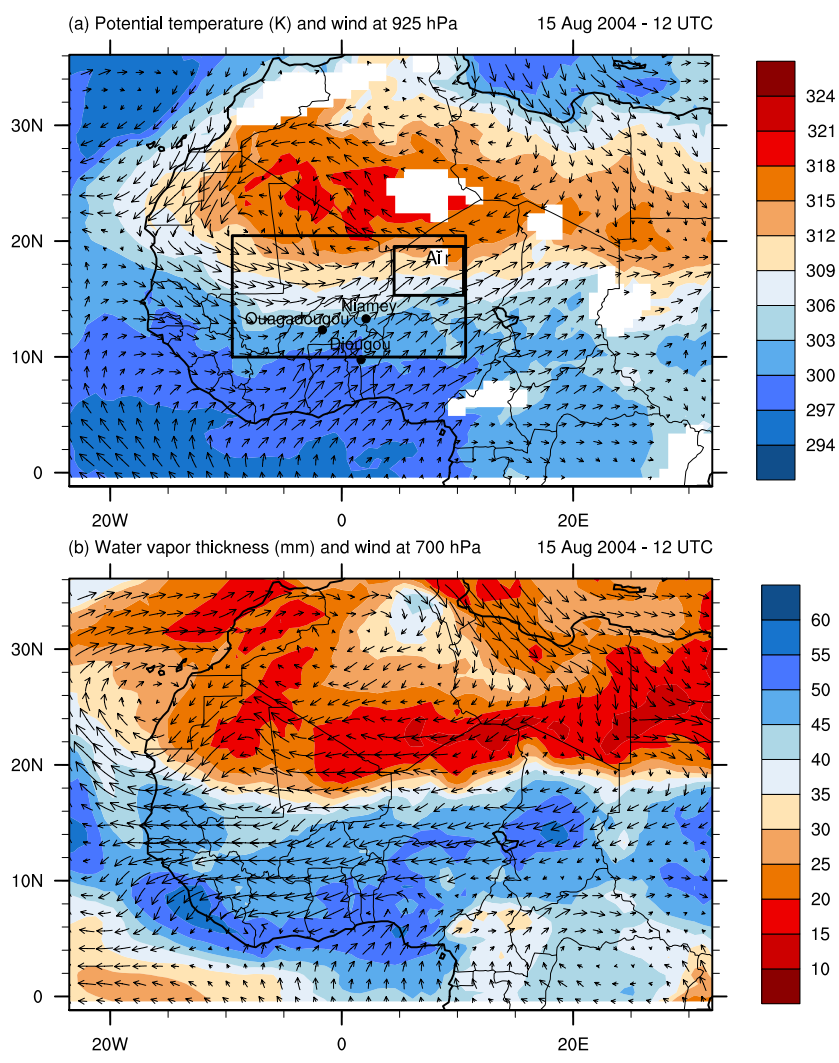

Fig. 1. Large-scale fields at 12:00 UTC 15 August 2004: (a) potential temperature $(\mathrm{K})$ and wind vectors at $925 \mathrm{hPa}$ and (b) water vapor thickness $(\mathrm{mm})$ and wind vectors at $700 \mathrm{hPa}$. The rectangles indicate the position of the two inner domains.

uble. Following Mullendore et al. (2005), five tracers were initially confined in layers from 0 . to $1.5 \mathrm{~km}, 1.5$ to $4.5 \mathrm{~km}$, 4.5 to $7.5 \mathrm{~km}, 7.5$ to $10 \mathrm{~km}$ and 10 to $20 \mathrm{~km}$. The first tracer, TR1, was initialized in the monsoon layer, close to the surface. The second tracer, TR2 was in the driest layer corresponding to the AEJ. TR3 and TR4 were initialized in the region above the AEJ but below the major convective cloud outflows. The last tracer, TR5, initially occupied the upper troposphere and lower stratosphere (UT/LS). The tracer is intended to represent air masses at the highest altitudes of the model but with no distinction between tropospheric and stratospheric origin. The role of this tracer was to eventually detect large scale subsidence associated with the convective cloud but not to trace fine stratosphere-troposphere exchange events. Another practical reason for not refining this altitude range is that increasing the number of tracers increases the numerical cost of the simulation.

\section{Meteorological situation on 15 and 16 August 2004}

The MCS born around 12:00 UTC on 15 August 2004 east of the Airr Mountains as seen with MSG observations (not 


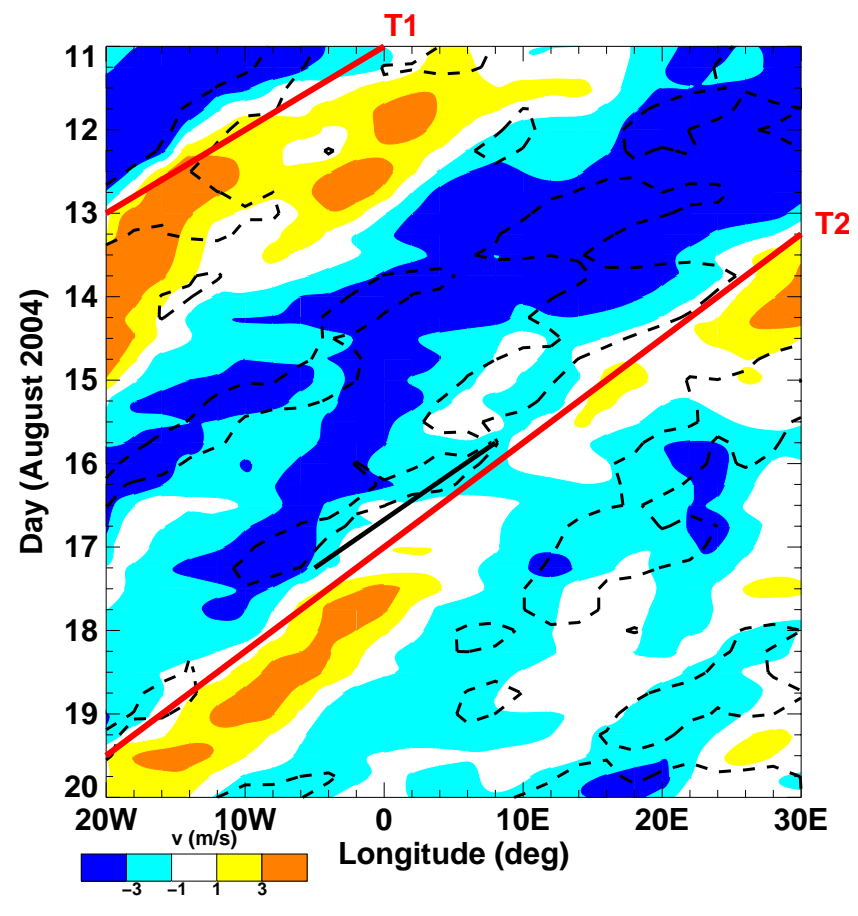

Fig. 2. Time-longitude diagram of 700-hPa meridional wind (color) and MSG 10.8- $\mu \mathrm{m}$ BT contour at $265 \mathrm{~K}$ (dashed line) averaged over $5^{\circ}-15^{\circ} \mathrm{N}$ from 11 to 20 August 2004. The black thick line indicates the location of the MCS in the simulation while the two red lines show the position of the troughs $\mathrm{T} 1$ and $\mathrm{T} 2$.

shown). The initiation of the MCS was a consequence of the convergence of the southwesterly monsoon flux and of the easterly winds at low levels, as decribed next. One hour later, the cloud developed vertically and the cloud top reached an altitude of $14 \mathrm{~km}$ just above the top of the mountains. The MCS then grew steadily while propagating southwestward during the afternoon and until 21:00 UTC. From 00:00 UTC 16 August onwards, the MCS split into two parts and further propagated westward to finally dissipated over the Guinea highlands at 00:00 UTC 17 August.

\subsection{Life-cycle of the MCS from analysis and observations}

The large scale environment of the MCS is illustrated at 12:00 UTC on 15 August at 925 and $700 \mathrm{hPa}$ over West Africa (Fig. 1). This simulation shows similar meridional kinematic and thermodynamic structure to the one derived from observed profiles by Parker et al. (2005). At $925 \mathrm{hPa}$, the potential temperature showed a strong meridional gradient with the largest values over the Sahara where a continental depression (also called "Heat Low") resides in summertime (Lavaysse et al., 2009; Chauvin et al., 2010; Lavaysse et al., 2010). This strong contrast from the Guinea coast to the Sahara drove the meridional circulation. Remarkably, the southwesterly monsoon flux penetrated deeply into the
African continent, up to the Aïr mountains at $18^{\circ} \mathrm{N}, 9^{\circ} \mathrm{E}$. Large values of water vapor thickness were found between $5^{\circ} \mathrm{N}$ and $15^{\circ} \mathrm{N}$, and over the Air mountains, in association with a strong AEJ at $700 \mathrm{hPa}$. These conditions are common during the summer period and lead to frequent convective developments over the Air moutains in the afternoon.

To underline the connection between African Easterly Wave (AEW) and convection, Fig. 2 presents a Hovmöller diagram of the 700-hPa meridional winds from ECMWF analyses, averaged between $5^{\circ} \mathrm{N}$ and $15^{\circ} \mathrm{N}$ for the 11-20 August 2004 period. The $265-\mathrm{K}$ isoline of the averaged $10.8-\mu \mathrm{m}$ BT observed from MSG was superimposed and used as a proxy for MCSs. This 10-day period was characterized by the prevalence of northerly winds at $700 \mathrm{hPa}$. Two African Easterly Wave troughs were characterized by a cyclonic change in the meridional wind component, and propagated westward: the first (T1) from $0^{\circ}$ at 12:00 UTC 11 August to $20^{\circ} \mathrm{W}$ at 00:00 UTC 13 August and the second (T2) from $30^{\circ} \mathrm{E}$ at 12:00 UTC 13 August to $20^{\circ} \mathrm{W}$ at 12:00 UTC 19 August. As in Berry and Thorncroft (2005) the location of the trough was defined as the zero value of the $700 \mathrm{hPa}$ meridional wind. Many studies (McBride and Gray, 1979; Barnes and Sieckman, 1984) have shown that the region ahead of the AEW trough, where north-easterly flow aloft both advects dry air equatorward and increases vertical shear, promote MCS organization as shown by the $265-\mathrm{K}$ MSG $10.8-\mu \mathrm{m}$ BT isoline in Fig. 2. The MCS studied here developed ahead of trough T2 from $5^{\circ} \mathrm{E}$ at 00:00 UTC 16 August. The simulated MCS (thick line in Fig. 2) was also located ahead of trough T2, but it propagated more slowly than in the actual observations. Together with the surge of the monsoon flow up to the Aïr mountains and the dry AEJ at $700 \mathrm{hPa}$, this situation was favorable for convection triggering.

\subsection{Life-cycle of the MCS from the simulation}

The Meso-NH simulation is now evaluated through the environmental conditions (Fig. 3), the MCS propagation (Fig. 4) and structure (Figs. 5 and 6). Figure $3 \mathrm{a}$ shows the vertical profile of equivalent potential temperature $\left(\theta_{\mathrm{e}}\right)$ averaged over the model-3 domain, prior to the MCS triggering. The strong gradient of $\theta_{\mathrm{e}}$ between the ground and $6 \mathrm{~km}$ altitude reached $-28 \mathrm{~K}$ due to the very dry midlevel $(329 \mathrm{~K})$ and the relatively warm and moist surface $(357 \mathrm{~K})$. Such a gradient is indicative of a significant initial convective instability (Lafore and Moncrieff, 1989). The vertical profiles of the zonal and meridional wind (Fig. $3 \mathrm{~b}-\mathrm{c}$ ) between 0 and $2 \mathrm{~km}$ altitude clearly show the signature of the southwesterly monsoon flow. This is consistent with the large-scale fields at 12:00 UTC that shows the penetration of the monsoon flux up to $18^{\circ} \mathrm{N}$. The water vapor profile (Fig. 3d) also shows the signature of the monsoon flow with high mixing ratio values $\sim 10-15 \mathrm{~g} \mathrm{~kg}^{-1}$ below $2 \mathrm{~km}$ altitude. Above $2 \mathrm{~km}$ altitude, the flow was mainly easterly (Fig. 3b), and reached $-10 \mathrm{~m} \mathrm{~s}^{-1}$ at $4 \mathrm{~km}$ which is the signature of the AEJ. Above, 
(a)

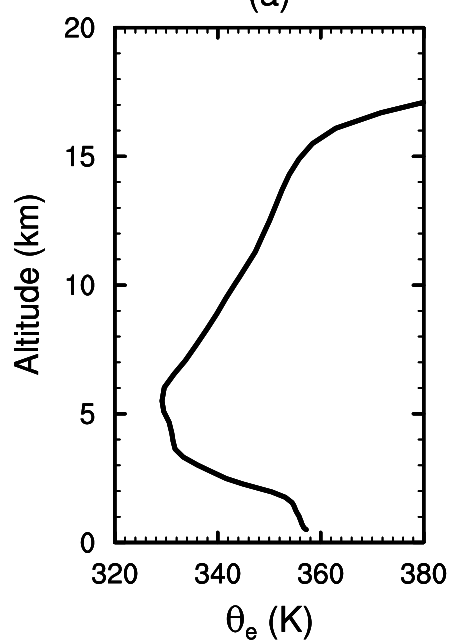

(b)

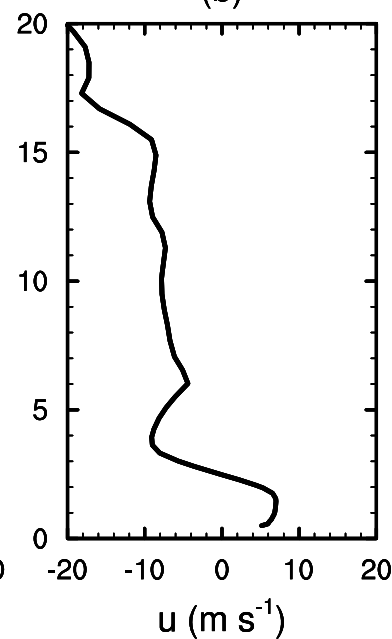

(c)

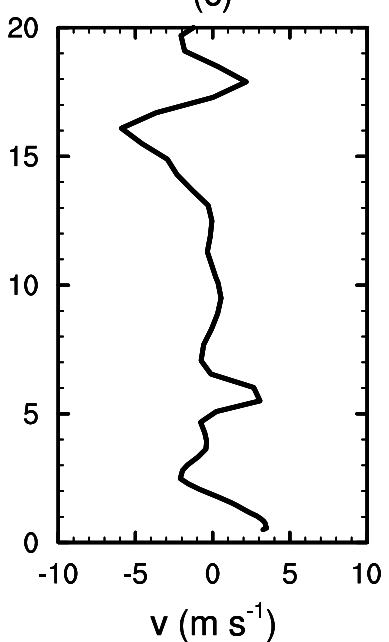

(d)

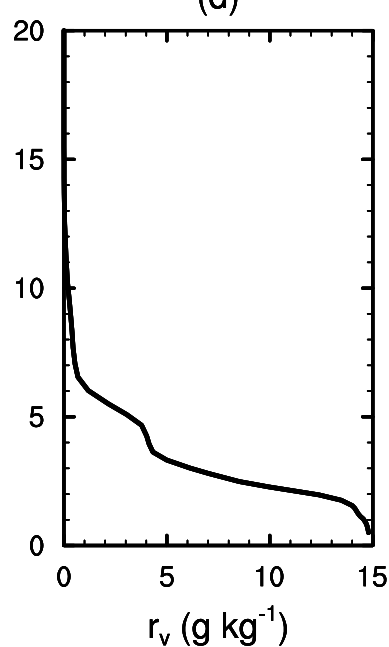

Fig. 3. (a) Equivalent potential temperature $\left(\theta_{\mathrm{e}}\right.$ in $\left.\mathrm{K}\right)$, (b) zonal $\left(u\right.$ in $\left.\mathrm{m} \mathrm{s}^{-1}\right)$ and (b) meridional wind $\left(v\right.$ in $\left.\mathrm{m} \mathrm{s}^{-1}\right)$, and (d) water vapor mixing ratio $\left(r_{\mathrm{V}}\right.$ in $\left.\mathrm{g} \mathrm{kg}^{-1}\right)$ profiles at 12:00 UTC 15 August 2004 averaged over the model-3 domain, prior to the triggering of the MCS.

the zonal wind was easterly and peaked $\left(10 \mathrm{~m} \mathrm{~s}^{-1}\right)$ at $13 \mathrm{~km}$ which corresponds to the TEJ.

The simulated MCS exhibits similarities with the observed one. Both were generated in the early afternoon of 15 August over the Aïr Mountains, then propagated southwestward. Figure 4 shows the Hovmöller diagram of the maximum radar reflectivity between 4.5 and $10.5^{\circ} \mathrm{E}$. As in MSG observations, convection was initiated around $9^{\circ} \mathrm{E}$ at 11:00 UTC. The maximum radar reflectivity exceeded $30 \mathrm{dBZ}$ one hour later. The system propagated westsouthwestward at $\sim 10 \mathrm{~m} \mathrm{~s}^{-1}$. From 16:00 UTC, another system was located ahead of the studied MCS (see Fig. 5). However, the horizontal extension of the observed MCS as depicted by the $10.8-\mu \mathrm{m}$ brightness temperature (hereinafter referred to as BT $(10.8 \mu \mathrm{m})$ ) is larger than the simulated one all along the afternoon (Fig. 5). After 20:00 UTC, the first MCS weakened and merged with the second MCS which revigorated. At 23:00 UTC, the MCS was out of the simulation domain. In terms of intensity, both the simulated and the observed MCSs had large areas of $10.8 \mu \mathrm{m}$ BT lower than $206.5 \mathrm{~K}$, though this area is significantly lower in the simulation. Thus, the convective area is probably lower in the simulation. This may also be a consequence of the high concentration of dust aerosols (that can serve as good ice nuclei) near the tropopause in this region (Tulet et al., 2010) which is not taken into account in the simulation. Therefore, the synthetic brightness temperature computed from the MesoNH microphysical variables with the RTTOV code may be impacted.

Figure 6 displays the horizontal cross-section of the maximum radar reflectivity simulated by Meso-NH at 19:00 UTC on 15 August. The MCS was located at $16.5^{\circ} \mathrm{N}, 7^{\circ} \mathrm{E}$, southwest of the Aïr Mountains. The system presents a classical

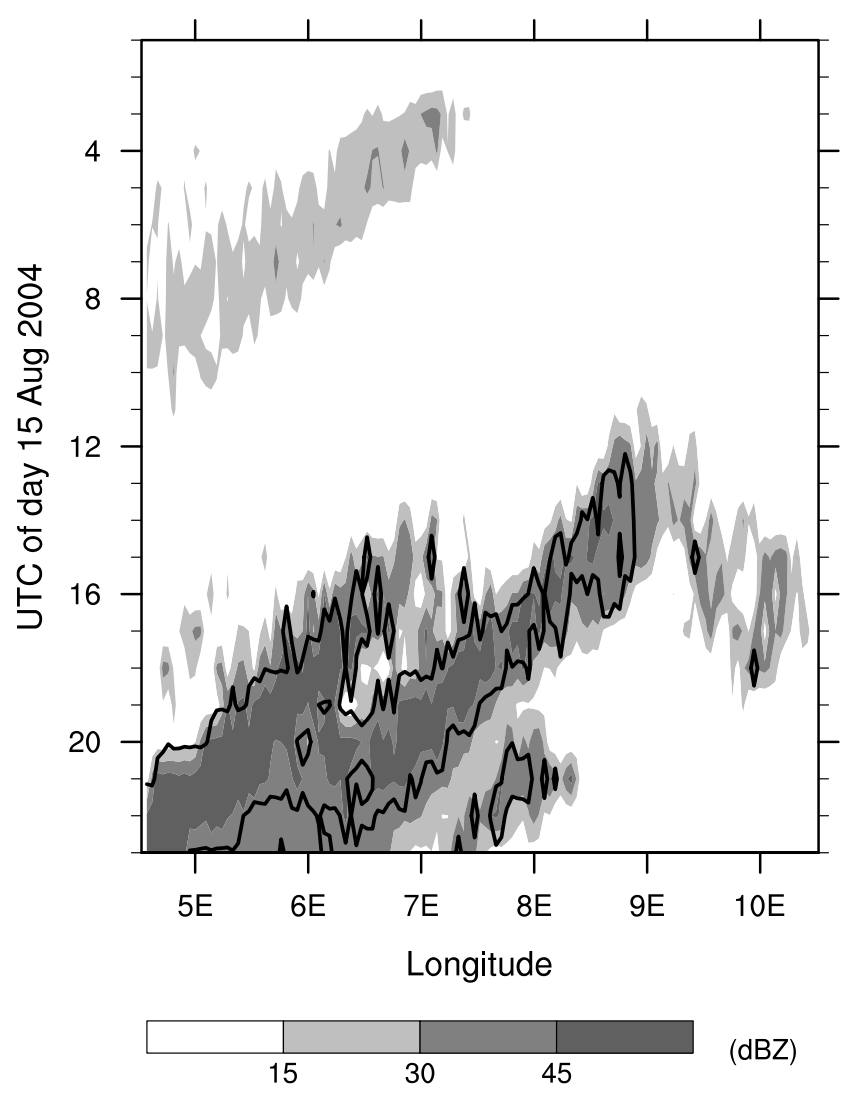

Fig. 4. Hovmöller plots from 15 August 2004 00:00 UTC to $16 \mathrm{Au}-$ gust 2004 11:00 UTC of the maximum radar reflectivity (dBZ) in a grid cell column simulated by Meso-NH (grey areas). The black line shows the $5 \mathrm{~mm} \mathrm{~h}^{-1}$ instantaneous precipitation rate. 

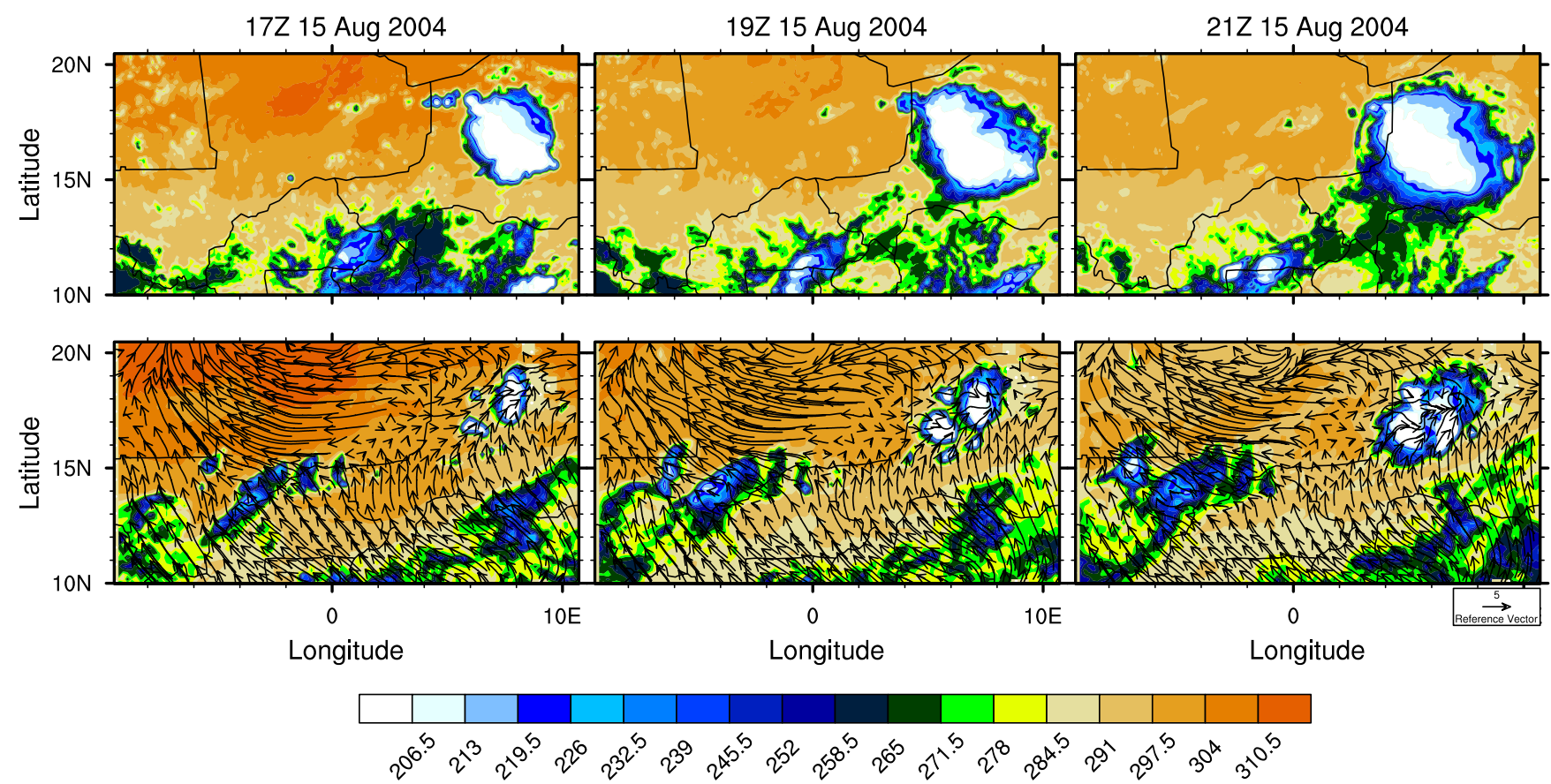

Fig. 5. Top: observed METEOSAT and bottom: simulated cloud-top infrared brightness temperature at 10.8 $\mu$ m for 15 August 2004 at 17:00, 19:00 and 21:00 UTC. Horizontal wind fields simulated by Meso-NH and relative to the motion of the MCS are shown at $6 \mathrm{~km}$ altitude.

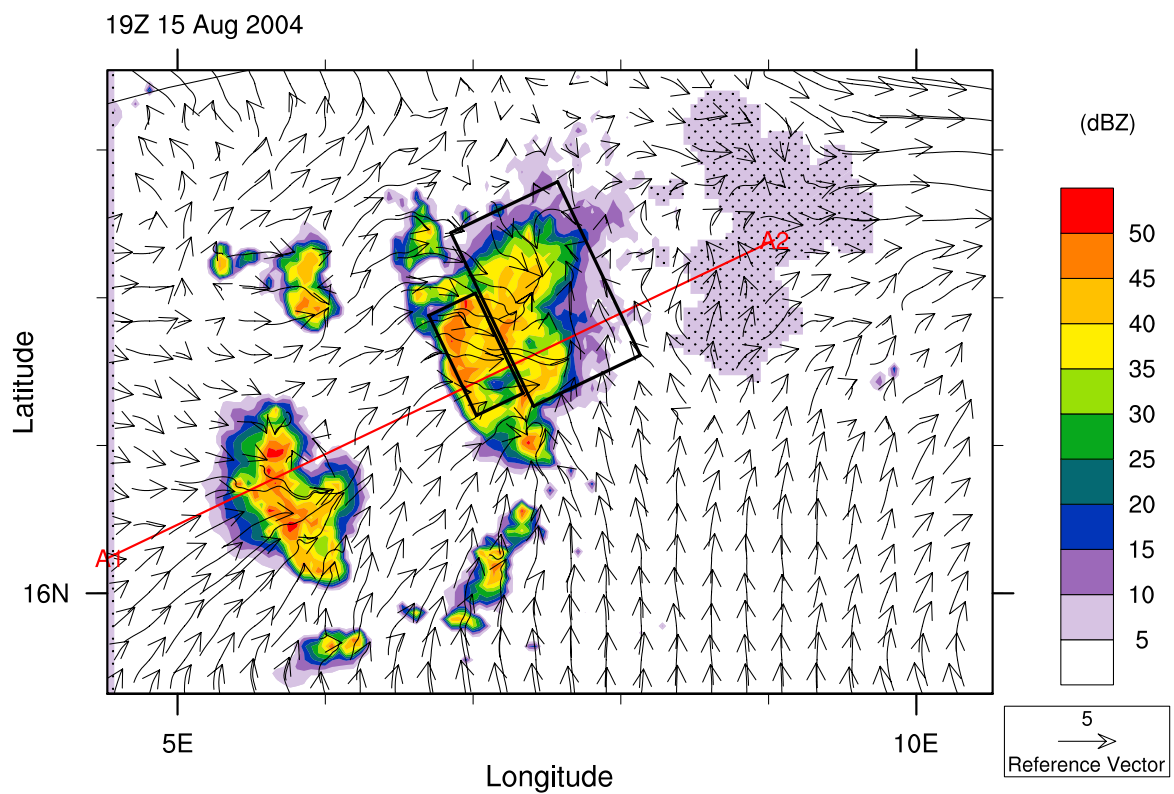

Fig. 6. Horizontal cross section of the maximum radar reflectivity (dBZ) in a grid cell column and the horizontal relative wind field at $5 \mathrm{~km}$ altitude on 15 August 2004 at 19:00 UTC simulated by Meso-NH. The black boxes delineate the convective and stratiform parts of the MCS used for budget calculations. The propagation axis is marked as a A1-A2 line. The dotted region corresponds to the Aïr orography higher than $1 \mathrm{~km}$.

organization with the leading line of convective cells with maximum reflectivity values exceeding $45 \mathrm{dBZ}$. At the rear of the convective region, the stratiform region shows lower reflectivity values $(\sim 40 \mathrm{dBZ})$. This allows us to define two regions: the convective region extends over $40 \mathrm{~km}$ while the stratiform region is $200-\mathrm{km}$ long. Another convective system was located $100 \mathrm{~km}$ southwestard of the studied MCS as also depicted in Fig. 6. Figure 7 shows the vertical velocity and 
(a)

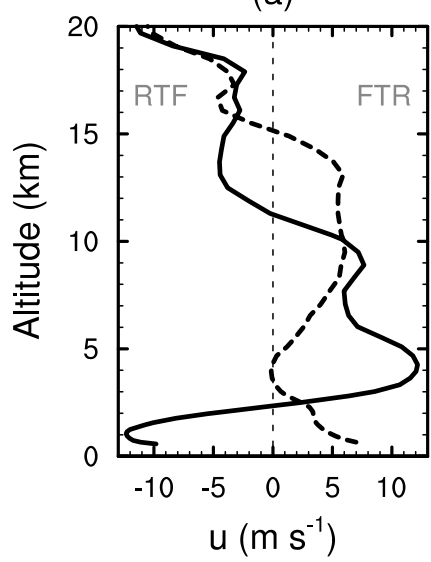

(b)

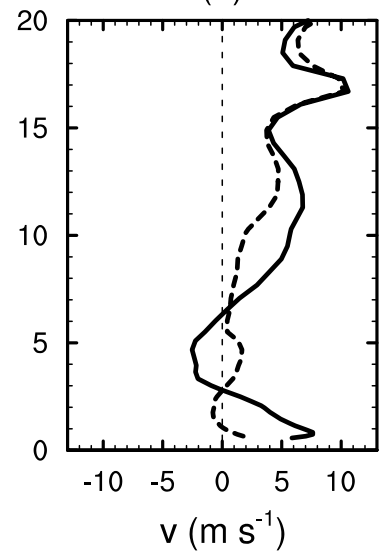

(c)

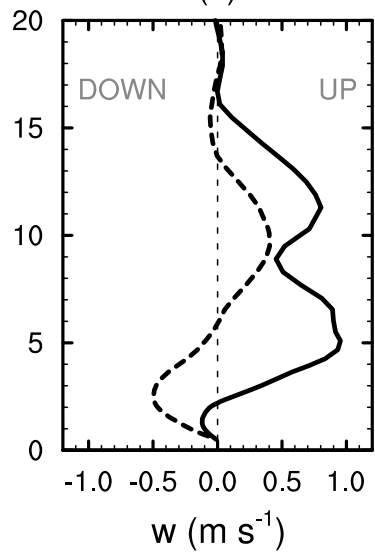

(d)

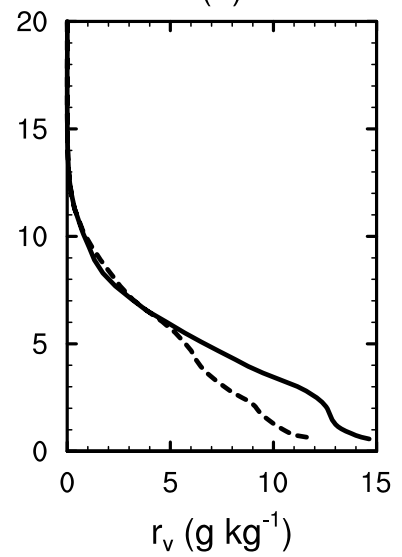

Fig. 7. (a) Cross line $(u)$ and (b) along line $(v)$ relative wind components, $(\mathbf{c})$ vertical velocity $(w)$, and (d) water vapor mixing ratio $\left(r_{\mathrm{V}}\right)$ profiles on 15 August 2004 at 19:00 UTC averaged over the convective (solid lines) and stratiform (dashed lines) regions defined in Fig. 6. In (a), negative and positive cross-line winds correspond to rear-to-front (RTF) and front-to-rear (FTR) flow, respectively. In (c), UP and DOWN stand for upward and downward motion, respectively.

system-relative horizontal wind components perpendicular to the MCS $(u)$ and along the MCS $(v)$, averaged in the convective and stratiform boxes (see Fig. 6). The convective region was characterized by strong updrafts (Fig. 7) compared to the stratiform region. Mean updraft speed in the convective area reached $1 \mathrm{~m} \mathrm{~s}^{-1}$ between 5 and $12 \mathrm{~km}$ altitude. Below $2 \mathrm{~km}$, a rear-to-front flow in the cold pool reached the convective leading edge (negative relative cross line wind component $u$ ). Between 2 and $3 \mathrm{~km}$, a strong front-to-rear flow fed the convective system with humid air $\left(r_{v} \sim 12-15 \mathrm{~g} \mathrm{~kg}^{-1}\right)$. This layer experienced an efficient entrainment of surrounding air in the cloud updraft as also seen in Fig. 10. The drier atmospheric layer between 3 and $5 \mathrm{~km}$ corresponds to the altitude of the AEJ with little inflows in the convective clouds. The depth of the rear-to-front flow behind the convective updraft is $2.5 \mathrm{~km}$ which is comparable to the estimation of Chong et al. (1987). Below $5 \mathrm{~km}$, the stratiform region experienced mean downward motion associated with a north-westward front-to-rear flow. This corresponds to the return branch of the so called "return flow". The system-relative airflow structure displayed the main features commonly observed in previous studies (Zipser, 1977; Roux et al., 1984; Roux, 1988; Houze et al., 1989; Caniaux et al., 1994; Parker and Johnson, 2004; Chong, 2010).

With regards to the MCS organization, radar reflectivity and brightness temperature intensities, the simulated MCS is comparable to commonly observed MCSs. It thus provides a representative West African cloud for the study of 3-D tracers transport.

\section{Tracer transport by a MCS}

\subsection{Redistribution of passive tracers}

\subsubsection{Temporal evolution of the tracers}

Figure 8 shows the temporal evolution of maximum vertical velocity and concentration of each tracer at different altitudes, and instantaneous precipitation rate. Tracer concentration and instantaneous precipitation rate are averaged over the sub-domain $\left(16.6-19.0^{\circ} \mathrm{N} ; 6.4-9.0^{\circ} \mathrm{E}\right)$, which encompasses the track of the MCS in the simulation. The maximum vertical velocity is used as an indicator of convection intensity. Between 02:00 and 08:00 UTC, before the triggering of the MCS, the maximum vertical velocity did not exceed $1 \mathrm{~m} \mathrm{~s}^{-1}$ (shallow convection) in the low- and mid-troposphere $(3 \mathrm{~km}, 6 \mathrm{~km}$ and $9 \mathrm{~km})$ and no precipitation was produced. The maximum vertical velocity began to increase around 12:00 UTC in the lower levels, and reached $13 \mathrm{~m} \mathrm{~s}^{-1}$ at $3 \mathrm{~km}$ altitude at 20:00 UTC. Some oscillations of the maximum vertical velocity between 15 and $40 \mathrm{~m} \mathrm{~s}^{-1}$ can be seen at 12 and $15 \mathrm{~km}$ altitude between 16:00 and 21:00 UTC. The precipitation was initiated at 13:00 UTC, peaked at 19:00 UTC $\left(0.6 \mathrm{~mm} \mathrm{~h}^{-1}\right)$, then decreased rapidly at 23:00 UTC after the MCS moved out of the sub-domain.

Between 02:00 and 08:00 UTC, the small vertical velocities simulated in the low- and mid-troposphere changed the concentration of TR1, TR2, TR3 and TR4 in their initial layer or immediatly above or below. However, the concentrations of tracers TR1, TR2 and TR3 were durably affected by this shallow convection at the lower levels $(3 \mathrm{~km})$. Above, the concentrations almost restored their initial value after 08:00 UTC. As soon as deep convection was triggered ( 12:00 UTC), concentration of tracers decreased in their 


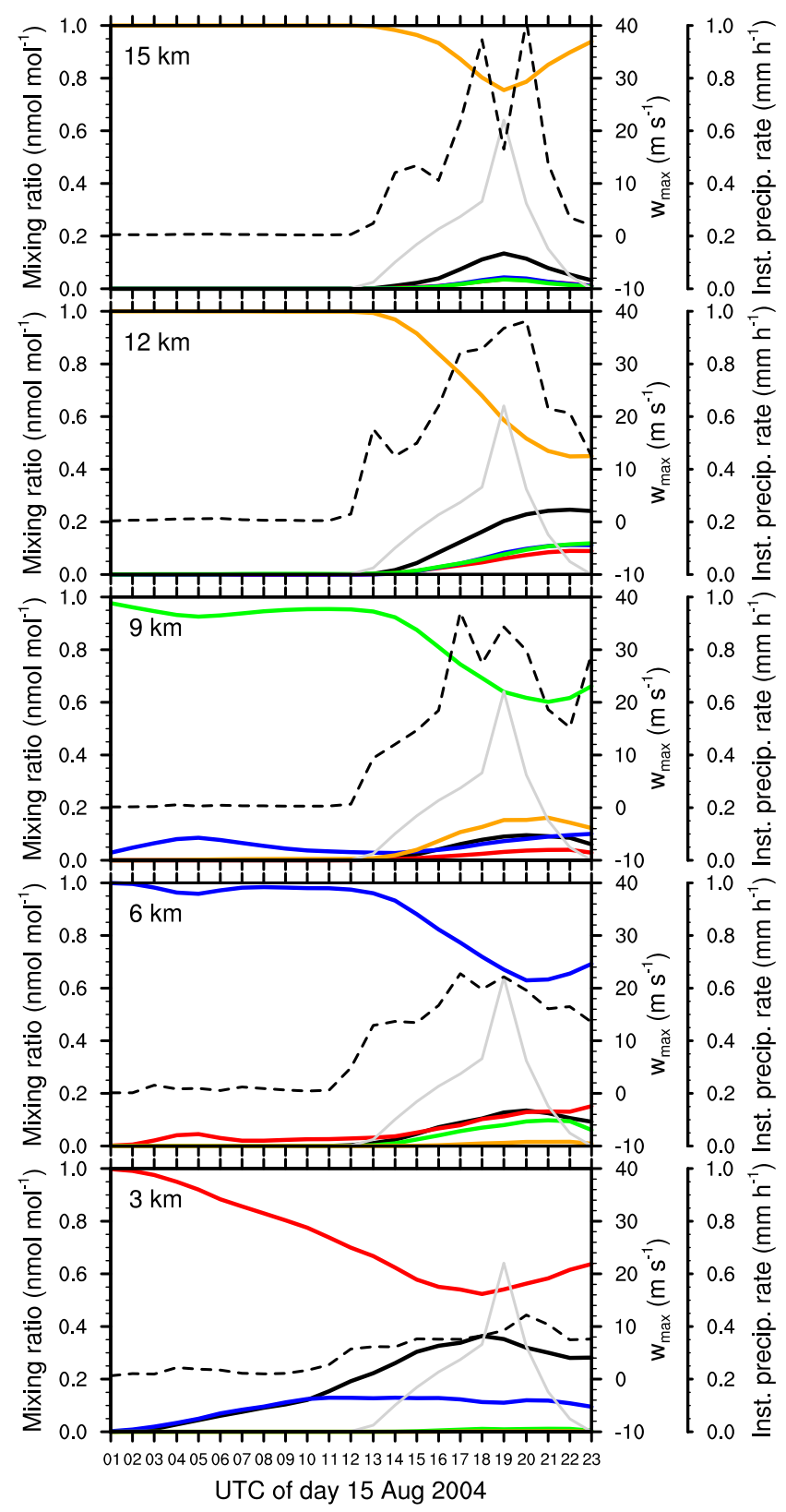

Fig. 8. Time evolution of the tracers mixing ratios $\left(\mathrm{nmol} \mathrm{mol}^{-1}\right)$ on 15 August 2004, TR1 (black), TR2 (red), TR3 (blue), TR4 (green) and TR5 (yellow) for five altitudes $(15 \mathrm{~km}, 12 \mathrm{~km}, 9 \mathrm{~km}$, $6 \mathrm{~km}$ and $3 \mathrm{~km}$ altitude). Black dashed and grey solid lines are maximum vertical velocity $\left(\mathrm{m} \mathrm{s}^{-1}\right)$ and instantaneous precipitation rate $\left(\mathrm{mm} \mathrm{h}^{-1}\right)$, respectively. The parameters are averaged over the subdomain $\left(16.6-19.0^{\circ} \mathrm{N} ; 6.4-9.0^{\circ} \mathrm{E}\right)$.

initial layer. TR1 was the most effectively transported upward tracer with concentrations of $0.35,0.13,0.10,0.26$ and $0.14 \mathrm{nmol} \mathrm{mol}^{-1}$ at $3,6,9,12$ and $15 \mathrm{~km}$, respectively. Mid-tropospheric TR2, TR3 and TR4 contributed very little to the airmass composition at $15 \mathrm{~km}$ height but all three enriched the atmosphere between $3 \mathrm{~km}$ and $12 \mathrm{~km}$. TR5

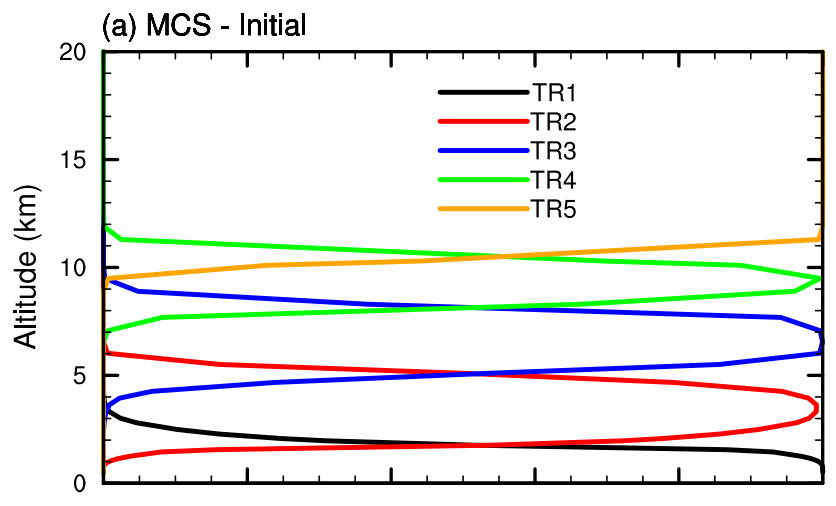

(b) Convective region

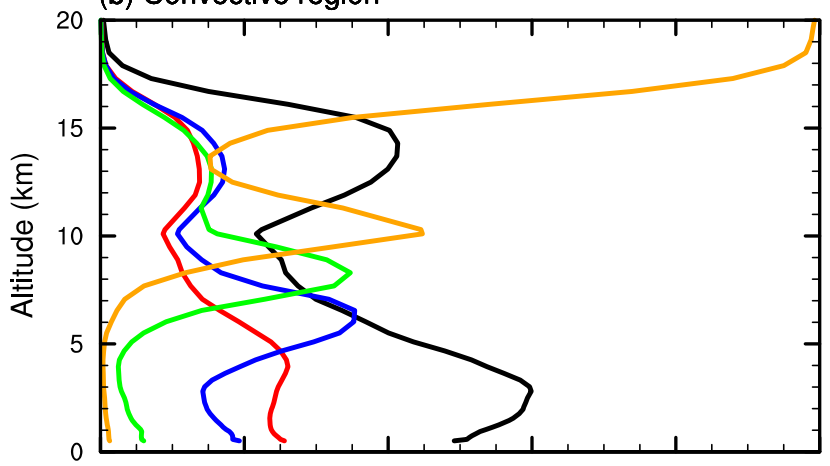

(c) Stratiform region

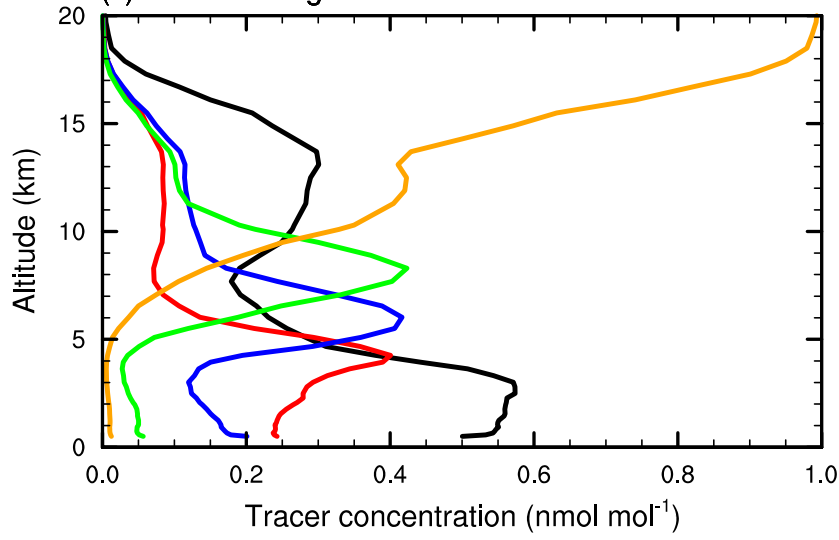

Fig. 9. Tracers concentrations $\left(\mathrm{nmol} \mathrm{mol}^{-1}\right)$ vertical profiles on 15 August 2004 at 02:00 UTC before the MCS triggering (a) and at 19:00 UTC in the convective (b) and stratiform (c) regions. In (a), the concentrations are averaged over the sub-domain $\left(16.6-19.0^{\circ} \mathrm{N}\right.$; 6.4-9.0 $\left.0^{\circ} \mathrm{E}\right)$. The convective and stratiform regions are defined as areas with instantaneous precipitation rate higher and lower than $5 \mathrm{~mm} \mathrm{~h}^{-1}$, respectively.

was not transported to the lowest levels. Most of the peaks in the tracer concentration at each level occurred between 18:00 UTC and 20:00 UTC, which corresponds to the peaks of vertical velocity. An exception is the tracers concentration at $12 \mathrm{~km}$ that reached a plateau from 20:00 UTC onwards. 
In the following, we will focus on the tracers transport at 19:00 UTC, the moment of the maximum upward velocities.

\subsubsection{Vertical distribution of the tracers}

At 19:00 UTC, in the convective region, the concentration of each tracer (Fig. 9b) in its original layer has decreased from the initial state (Fig. 9a). TR1, TR2, TR3 and TR4 are now distributed over the whole cloud height, from the ground up to $18 \mathrm{~km}$ altitude. TR1 was efficiently transported by the convective updrafts in altitude, with a first maximum at $2.5 \mathrm{~km}$ $\left(0.57 \mathrm{nmol} \mathrm{mol}^{-1}\right)$, above the upper limit of its initial layer, and a secondary one at $14 \mathrm{~km}\left(0.43 \mathrm{nmol} \mathrm{mol}^{-1}\right)$. The atmospheric layer between 12 and $15 \mathrm{~km}$ corresponds to the main convective outflow region characterized by strong vertical velocity (Fig. 8). TR2, TR3 and TR4 show a similar vertical distribution, with a first maximum close to their initial altitudes, at $4 \mathrm{~km}\left(0.28 \mathrm{nmol} \mathrm{mol}^{-1}\right), 6 \mathrm{~km}\left(0.36 \mathrm{nmol} \mathrm{mol}^{-1}\right)$ and $8 \mathrm{~km}\left(0.35 \mathrm{nmol} \mathrm{mol}^{-1}\right)$, respectively, and a second peak at $13-14 \mathrm{~km}$ altitude $\left(\sim 0.16 \mathrm{nmol} \mathrm{mol}^{-1}\right)$. It is worth noting that TR2, TR3 and TR4 concentrations were increased near the ground $\left(0.25,0.20\right.$ and $0.06 \mathrm{nmol} \mathrm{mol}^{-1}$, respectively) as a direct consequence of the downdrafts in the convective region. The UT/LS tracer TR5 exhibits a well marked minimum $\left(0.15 \mathrm{nmol} \mathrm{mol}^{-1}\right)$ at the main cloud detrainment level, between $13-14 \mathrm{~km}$ altitude. This minimum signs the convective upward transport of TR5 poor air masses from the lower levels. Above the cloud $(20 \mathrm{~km})$, the concentration of TR5 is almost $1 \mathrm{nmol} \mathrm{mol}^{-1}$ which shows that air at this altitude was weakly affected by the MCS dynamics. The redistribution of tracers by the MCS reveals that the upper troposphere was fed not only by boundary layer air masses (TR1) but also by mid-tropospheric air masses (TR2, TR3 and TR4). For example, at $14 \mathrm{~km}$, in the detrainment cloud anvil, for a total tracer mixing ratio of $0.90 \mathrm{nmol} \mathrm{mol}^{-1}$, half of it originates from the mid-troposphere between 2 and $10 \mathrm{~km}$ altitude (Fig. 9). This result highlights the role of mid-tropospheric entrainment in convective systems already shown in Mari et al. (2000), Mari et al. (2003) and Lopez et al. (2006), and questions the simplified approach for the convection efficiency calculation based on boundary layer and upper tropospheric concentrations only (Cohan et al., 1999; Bertram et al., 2007).

In the stratiform region (Fig. 9c), the vertical profiles of the tracers concentration are fairly similar to the convection ones, but some differences may be noted. The secondary maximum of TR1, TR2, TR3 and TR4 concentration in the $12-15 \mathrm{~km}$ altitude layer corresponds to the rearward outflows detrainment and is significantly reduced compared to the convective region. At this altitude, the minimum of TR5 concentration is less pronounced than in the convective region. It is worth noting that about the same concentrations of each tracer are found at the ground. It is also interesting to note that TR2, which was initialized in the AEJ layer has the lowest contribution above $5 \mathrm{~km}$ in both the convective and stratiform region in accordance with Lafore and Moncrieff (1989).

\subsubsection{Analysis of the tracer transport across the MCS}

To investigate which dynamical features are responsible for such vertical distributions of the tracers, the tracer transport along with the wind component across the MCS are analyzed. Figure 10 shows the perturbation of the horizontal component of the wind from the initial wind field at 19:00 UTC. In the low levels, there is a rear-to-front perturbation both at the front and at the rear of the system. This is different from the numerical results of Lafore and Moncrieff (1989) who found a rear-to-front low level perturbation associated with the rotor, and a front-to-rear low level perturbation at the leading edge of their 2-D simulated MCS. Here, a first system was located only $100 \mathrm{~km}$ ahead of the studied MCS and therefore may influence the circulation behind it. This rear-to-front flow below $5 \mathrm{~km}$ in the stratiform region can explain the concentration of TR2, TR3 and TR4 at the ground (Fig. 9). A front-to-rear flow between 2.5 and $6 \mathrm{~km}$ altitude was found ahead of the MCS in agreement with Lafore and Moncrieff (1989). Above $10 \mathrm{~km}$, one can observe an horizontal divergence that acted to reduce (intensify) the TEJ behind (ahead) of the MCS (at the horizontal distance of $190 \mathrm{~km}$ in Fig. 10).

The front side of the two successive systems gives an overview of the tracer distribution before the MCS passage. The tracers mainly remained unperturbed with maximum concentration in the middle of their initial layer $>0.9 \mathrm{nmol} \mathrm{mol}^{-1}$, but in a broader region. An exception is that TR2 can be found down to the ground with concentration $\sim 0.1 \mathrm{nmol} \mathrm{mol}{ }^{-1}$ between the ground and the lower limit of its initial layer (Fig. 10). This is in agreement with the finding of Fig. 9 that shows the shallow convection in the morning that acted to disperse the low level tracers just below and above their initial layers.

Inside the main MCS, the five tracers were present in the anvil in various concentrations. TR1 was transported upward in the updrafts and diluted by the divergence above $10 \mathrm{~km}$ altitude in the front and rear anvils. TR1 shows significant values in the anvil $\left(0.4 \mathrm{nmol} \mathrm{mol}^{-1}\right)$ while its concentration varies between 0.2 and $0.8 \mathrm{nmol} \mathrm{mol}^{-1}$ in its initial layer inside the cloud. While traces of TR2, TR3 and TR4 are present in the anvil, their concentrations $(\sim 0.1-$ $0.2 \mathrm{nmol} \mathrm{mol}^{-1}$ ) are less important than TR1. Thus, TR1 is the tracer the most efficiently transported in altitude with concentrations 3 to 4 times more important than the other tracers in the anvil. The UT/LS tracer TR5 was "pushed" upward by the updrafts and the associated upper level divergence, and consequently, low concentrations of TR5 are found in the anvil $\left(<0.2 \mathrm{nmol} \mathrm{mol}^{-1}\right)$ while a very strong gradient of concentration is observed at the edge of the cloud. The relatively high concentration of TR5 at the front of the system at $8-10 \mathrm{~km}$ altitude may be due to a downdraft located 

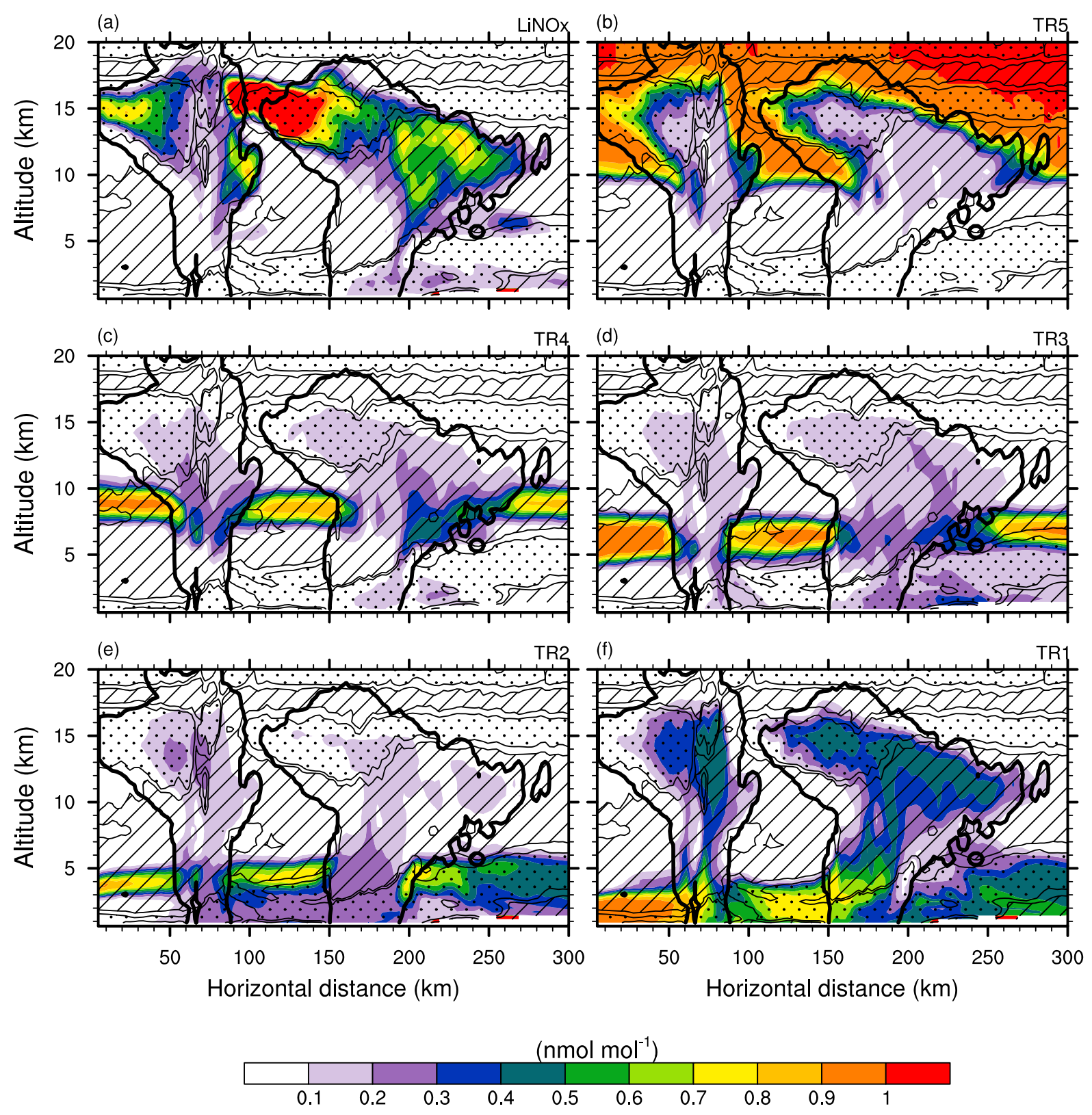

Fig. 10. Vertical cross section along the propagation axis (segment [A1 A2] in Fig. 6) of the tracers concentration (nmol mol ${ }^{-1}$ ) and of the perturbation of the horizontal component of the wind velocity from the initial wind field (dashed and dotted patterns are for the positive and negative values, respectively) on 15 August 2004 at 19:00 UTC. The contours for the horizontal wind perturbation are plotted at $\pm 1.5 \mathrm{~m} \mathrm{~s}^{-1}$. The black solid line shows the cloud contour.

just ahead of the convective updraft and originating from the evaporation of ice crystals falling from the leading anvil (Lafore and Moncrieff, 1989; Roux, 1988). It is worth noting that the simulated convective system does not show significant downward transport of upper tropospheric tracer below $5 \mathrm{~km}$. This result is in contradiction with the recent works of Grant et al. (2008) and Hu et al. (2010) who explain the increase of surface ozone by an efficient downward transport from the upper troposphere.
The tracers have different vertical distributions after the MCS passage. Lowest levels tracers TR1 and TR2 were significantly reduced in their initial layers $\left(<0.6 \mathrm{nmol} \mathrm{mol}^{-1}\right)$. The decrease of post-convective mixing ratios for TR3, TR4 and TR5 is less important and these tracers remained trapped in slightly thinner stratified layers compared to initial ones. At the rear of the system, the front-to-rear perturbation between $1.5 \mathrm{~km}$ and $5 \mathrm{~km}$ altitude overlays a front-to-rear perturbation. Thus the tracers present in the $[1.5-5] \mathrm{km}$ layer 
(TR1 and TR2) may also enter the system from the rear with the mesoscale inflow. A fraction of these tracers was then expelled rearward by the downward outflow. As in Lafore and Moncrieff (1989), a larger proportion of TR2 and TR3 was transported downwards, whereas a smaller proportion of these tracers was transported upwards.

\subsection{Redistribution of the lightning-produced $\mathrm{NO}_{\mathrm{x}}$ tracer}

A tracer was also introduced to mimic the $\mathrm{NO}_{\mathrm{x}}$ produced by lightning (hereafter called LiNOx). A crude LiNOx parameterization was used in the inner domain. When the maximum vertical velocity reached a threshold value $\left(\sim 15 \mathrm{~m} \mathrm{~s}^{-1}\right)$ (Barthe and Barth, 2008) and the three ice categories (ice crystals, snow and graupel) were present in the cloud, the first lightning was triggered with a lag of $8 \mathrm{~min}$ to mimic the time necessary for the building of the electric field (Barthe and Pinty, 2007). A mean flash rate of 10 flashes per minute was fixed. Assuming a mean flash length of $100 \mathrm{~km}$, the points where NO molecules are distributed were randomly chosen among the points where ice hydrometeors were present. The number of NO molecules distributed at each grid point depended on the flash length and altitude following Wang et al. (1998). The aim of this parameterization was to see how a tracer initially located or produced in the convective core of the MCS is redistributed in the whole system.

The LiNOx tracer was present in the whole anvil with two distinct maxima at the front $\left(1 \mathrm{nmol} \mathrm{mol}{ }^{-1}\right)$ and at the rear $\left(0.9 \mathrm{nmol} \mathrm{mol}^{-1}\right)$ of the system in relation to the upper level divergence. In the convective region, LiNOx were only found above $8 \mathrm{~km}$ altitude, with the maximum concentration in the front anvil. Since they were produced in the iced region of the cloud (above the $0^{\circ} \mathrm{C}$ isotherm), this tracer behaves like TR3, TR4 and TR5 which were uplifted by the convective updraft, then depleted from the convective core. In the stratiform part, LiNOx can be produced locally or advected from the convective region by the front-to-rear flow. A small part of the LiNOx tracer was transported to the ground, probably by the mesoscale rear-to-front downdraft.

In order to decide between local production and advection from the convective core in the front and rear anvil, new simulations with a LiNOx parameterization or an explicit electrical schemes might be conducted.

\subsection{Cloud-scale budgets of tracers transport}

In order to study the separate role of convective and stratiform components of the MCS in the three-dimensional airflow patterns and transport efficiency, a cloud-scale budget was calculated every hour from 16:00 to 21:00 UTC. Convective and stratiform box regions for budget calculation were defined as rectangular areas in which instantaneous precipitation exceeds $5 \mathrm{~mm} \mathrm{~h}^{-1}$ and is less than $5 \mathrm{~mm} \mathrm{~h}^{-1}$, respectively. An example of such boxes is shown at 19:00 UTC on Fig. 6. The orientation of the boxes is defined according to the propagation axis of the MCS. The mass $M_{\mathrm{z}}\left(\mathrm{kg} \mathrm{s}^{-1}\right)$ of air transported vertically through a horizontal rectangular area $A$ per unit time is expressed as:

$$
M_{\mathrm{Z}}(z)=\rho(z) w(z) A
$$

where $\rho$ is the air density and $w$ the vertical velocity over $A$ at the reference level $z . M_{\mathrm{Z}}$ is commonly called the convective mass flux. The net vertical mass $F_{\mathrm{Z}}$ can be calculated as the differential mass transport between two horizontal surfaces $A$ separated by a vertical height $\Delta z$ (Chong et al., 1987):

$F_{\mathrm{Z}}(z+\Delta z / 2)=M_{\mathrm{Z}}(z)-M_{\mathrm{Z}}(z+\Delta z)$

The differential horizontal mass transports $F_{\mathrm{x}}$ and $F_{\mathrm{y}}$ $\left(\mathrm{kg} \mathrm{s}^{-1}\right)$ through the respective vertical sections $L_{\mathrm{y}} \Delta z$ and $L_{\mathrm{x}} \Delta z$ can be calculated in a similar way. $F_{\mathrm{x}}$ and $F_{\mathrm{y}}$ are the horizontal flux convergence components perpendicular and parallel to the MCS respectively. Positive (negative) value of $F_{\mathrm{x}}, F_{\mathrm{y}}, F_{\mathrm{z}}$ indicates a net convergence (divergence). In the following $-F_{\mathrm{Z}}$ is discussed in terms of horizontal flux convergence (divergence) if positive (negative). Horizontal fluxes are calculated using the system-relative horizontal velocity components, but their divergence is independant of the propagation speed.

Figure 11 shows the vertical profiles of the air mass flux and mass flux convergence components in the convective and the stratiform regions each hour from 16:00 UTC to 21:00 UTC. First, the air mass flux and mass flux convergence components in the convective region are examined. At all times, the convective mass flux indicates a general upward mass transport $\left(M_{\mathrm{Z}}>0\right)$ which decreases rapidly around $15 \mathrm{~km}$ altitude. Below $4 \mathrm{~km}$, the horizontal flux convergence $\left(-F_{\mathrm{Z}}>0\right)$ at every time was mainly driven by perpendicular (front-to-rear) flux convergence $\left(F_{\mathrm{X}}>0\right)$. Above $10 \mathrm{~km}$ altitude, the perpendicular flux diverges $\left(F_{\mathrm{X}}<0\right)$ except at 20:00 UTC at the end of the MCS lifetime. This leads to a strong decrease of the upward mass transport $M_{\mathrm{z}}$. Detrainment in the upper troposphere above $10 \mathrm{~km}$ altitude is seen during the first four hours of the cloud lifetime. It is worth noting that detrainment also occurs in the mid-troposphere between $3 \mathrm{~km}$ and $10 \mathrm{~km}$ altitude. The maximum of detrainment was obtained at the early stage of the cloud formation (16:00 UTC) with $110 \times 10^{9} \mathrm{~kg} \mathrm{~s}^{-1}$ of air detrained back to the environment in the upper troposphere, and at the end of the MCS lifetime (20:00 UTC) with $115 \times 10^{9} \mathrm{~kg} \mathrm{~s}^{-1}$ of air detrained back to the environment in the mid-troposphere. At 16:00 UTC, only $41 \%$ of the air detrained above $10 \mathrm{~km}$ originated from the lower levels of the troposphere. Below $5 \mathrm{~km}$, parallel fluxes contribute mainly to the detrainment of air out of the cloud. At 16:00 and 18:00 UTC, the vertical profile of the parallel flux above $10 \mathrm{~km}$ signs entrainment of surrounding air $\left(F_{\mathrm{y}}>0\right)$ in the upper part of the cloud by parallel fluxes. Parallel fluxes can also have an opposite effect and contribute to increase the net detrainment rate in the upper troposphere (19:00 UTC). At the end of the MCS lifetime 
Convective region
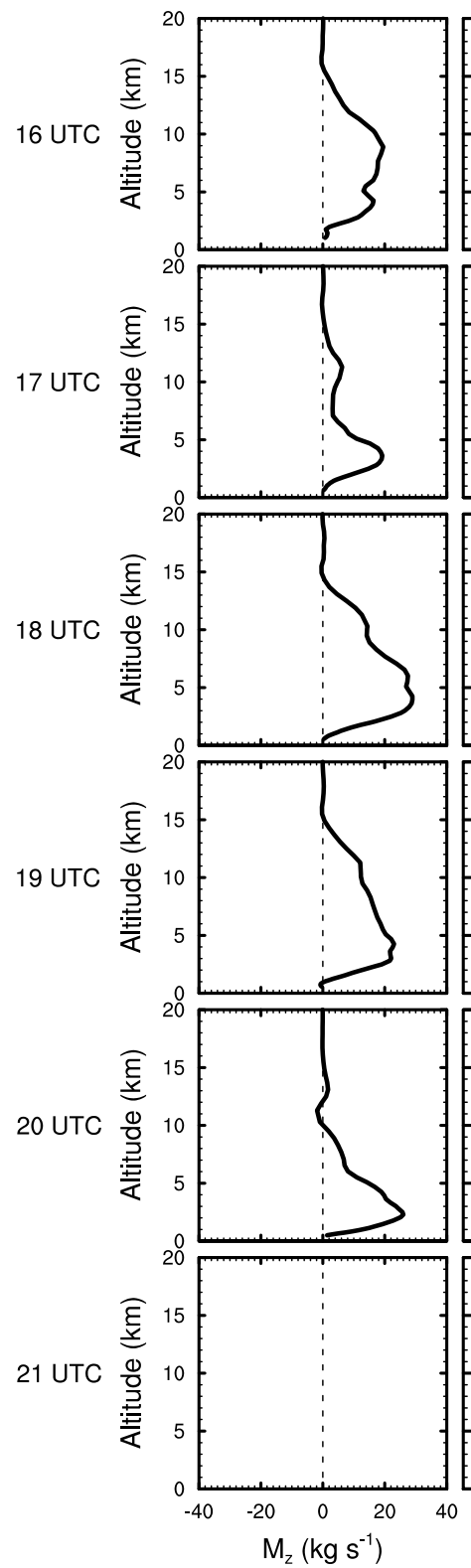
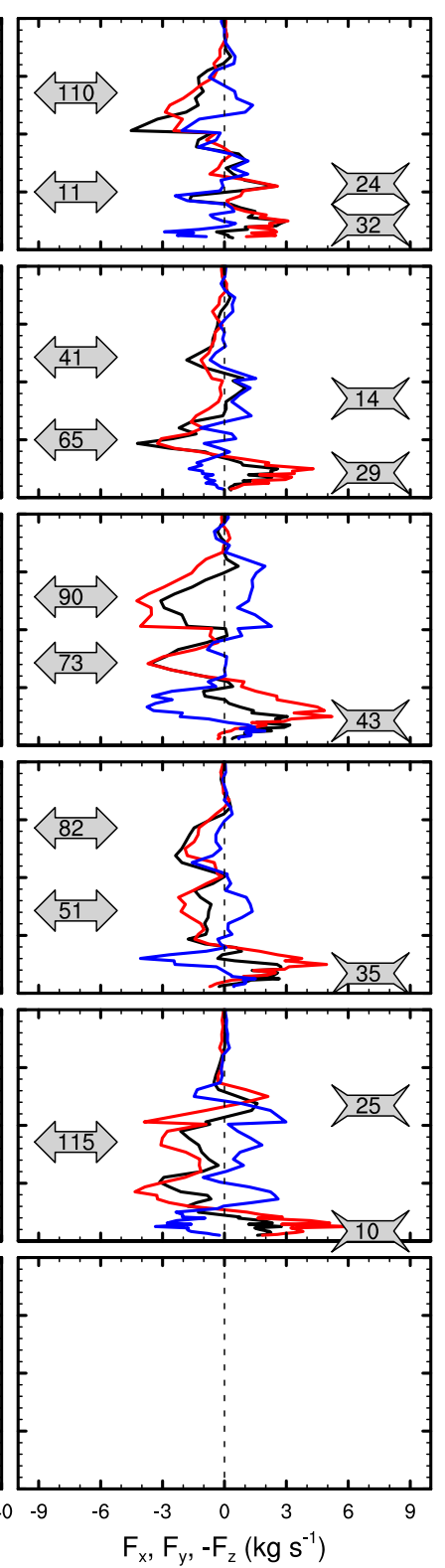

Stratiform region
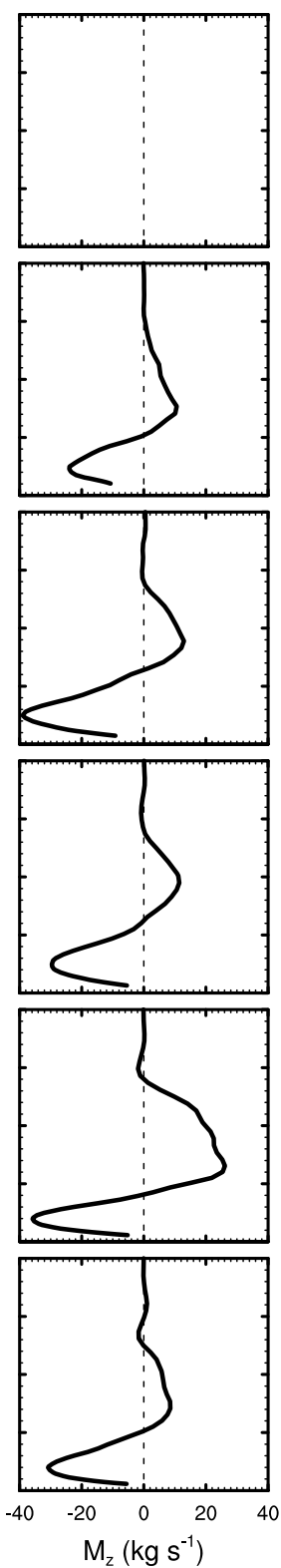
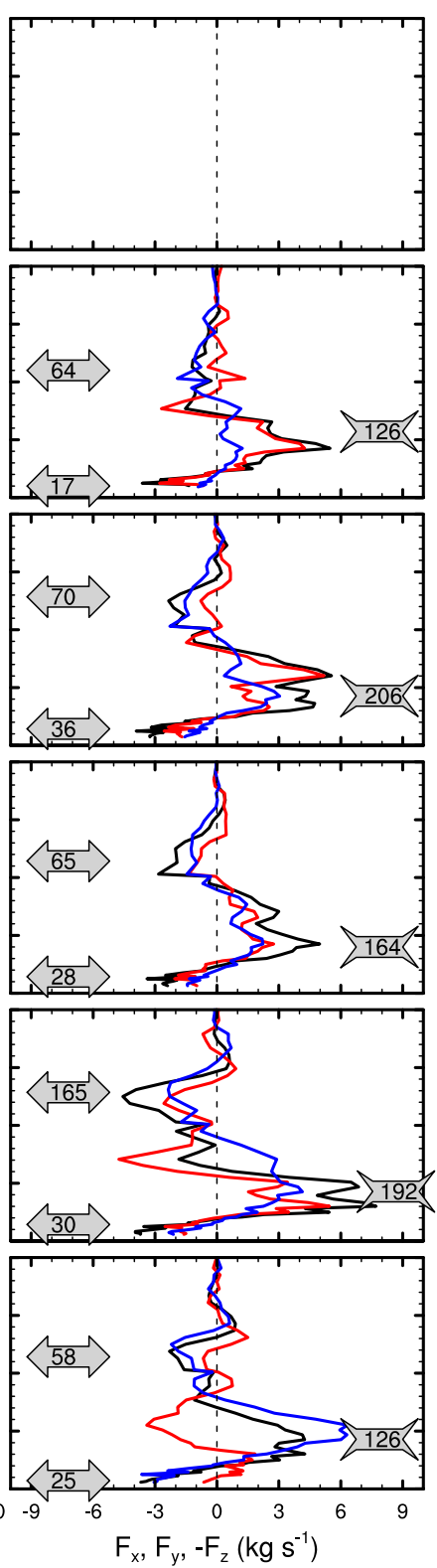

Fig. 11. Result of mass transport budget of the MCS in the convective (two columns left) and stratiform (two colums right) regions every hour from 15 August 2004 at 16:00 UTC to 21:00 UTC (1st and 3rd column). Vertical profile of air mass flux $M_{\mathrm{Z}}$ in $10^{9} \mathrm{~kg} \mathrm{~s}{ }^{-1}$ (2nd and 4th column). Vertical profiles of line-transverse $F_{\mathrm{X}}$ (red), line-parallel $F_{\mathrm{y}}$ (blue) and vertical $-F_{\mathrm{Z}}$ (black) mass fluxes convergences in $10^{9} \mathrm{~kg} \mathrm{~s}^{-1}$. The grey arrows represent the entrainment/detrainment air mass fluxes (in $10^{9} \mathrm{~kg} \mathrm{~s}^{-1}$ ).

(20:00 UTC), there was only one maximum of detrainment in the mid-troposphere, while two maxima of entrainment were simulated in the lower and upper troposphere.

The stratiform region is characterized by downdraft flows below $5 \mathrm{~km}$ altitude and upward flows above. From 18:00 UTC, downdraft transport occurs above $14 \mathrm{~km}$. Convergence in the stratiform region between $3 \mathrm{~km}$ and $7 \mathrm{~km}$ is driven by both parallel and transverse fluxes $\left(F_{\mathrm{x}}\right.$ and $\left.F_{\mathrm{y}}>0\right)$ at each time, as already shown by Roux and Sun (1990).
The layer of convergence between 2.5 and $10 \mathrm{~km}$, with divergence both above and below this layer, was also observed by Gamache and Houze (1982) and Chong et al. (1987). At each time, the upper level divergence $\left(17-36 \times 10^{9} \mathrm{~kg} \mathrm{~s}^{-1}\right)$ is higher than the lower level divergence $\left(58-165 \times 10^{9} \mathrm{~kg} \mathrm{~s}^{-1}\right)$. The line-parallel flux convergence $F_{\mathrm{y}}$ has a large contribution between 3 and $9 \mathrm{~km}$ altitude, in particular from 18:00 UTC. This means that the lateral inflows contribute significantly to the mesoscale updraft and downdraft. 


\section{Conclusions}

This study analysed the 3-D simulated mass transport from the troposphere to the upper troposphere associated with a MCS over Niger, east of Niamey on 15 August 2004. A MCS was triggered ahead of a trough, in a region with large humidity in the low levels associated to the southwesterly monsoon flow, and dry air at $700 \mathrm{hPa}$. This MCS originated from the Aïr mountains on 15 August and propagated southwestard.

In order to have an integrated view of entrainment and detrainment flows associated with the convective system, five passive tracers were initially confined within horizontal homogeneous layers. In the low levels, TR1 and TR2 originated from the monsoon layer and from the dry AEJ layer, respectively. TR1, which originated from the boundary layer, was the tracer the most efficiently transported upward. Its concentration in the anvil was 3 to 4 times higher than the concentration of the four others. TR2 had the lowest contribution above $5 \mathrm{~km}$ altitude in both the convective and stratiform regions. After the MCS passage, TR1 and TR2 concentrations were significantly reduced in their original layer. They were found in a broader layer extending between the ground and $5.5 \mathrm{~km}$ altitude.

The mid-tropospheric tracers TR3 and TR4 mixing ratios after the MCS passage peaked in their initial layer and around $13-14 \mathrm{~km}$ altitude, in both the convective and stratiform regions, emphasizing the role of mid-tropospheric air in feeding the upper troposphere. All mid-tropospheric tracers were efficiently transported by convective downdrafts with consequent increase of their concentrations at the surface.

The UT/LS tracer, TR5, was almost not transported down to $5 \mathrm{~km}$ altitude. Since the concentration of TR5 at $20 \mathrm{~km}$ altitude was similar to its initial value, this means that air at this altitude was not significantly affected by the MCS. The main feature of TR5 vertical distribution is the minimum simulated in the upper troposphere due to the convective upward transport of TR5 poor airmasses from the boundary layer. TR5 was not efficiently entrained into the cloud, and recovers its initial value once the MCS has passed. This suggests that the polluted air masses transported by the TEJ from the Asian continent through the Indian ocean are not significantly affected by the MCS.

Compared to previous modeling studies of tracer transport in a tropical MCS (Lafore and Moncrieff, 1989; Yasunaga et al., 2004), the simulation of this MCS was realized in 3$\mathrm{D}$, allowing to investigate the role of the lateral inflow. It was shown that the along-line component of the flux contributes significantly to the mesoscale updraft and downdraft between 3 and $9 \mathrm{~km}$ altitude in the stratiform region. Two peaks of detrainment were simulated both in the convective and the stratiform regions. However, if the higher peak was at about the same altitude $(10-15 \mathrm{~km})$ in the two regions, the second peak was located in the mid-troposphere $(5-10 \mathrm{~km})$ in the convective region, and at low levels $(0-2 \mathrm{~km})$ in the stratiform region. The relative importance of mid-level de- trainment and entrainment highlighted in this study is still a challenging issue for current convective parameterizations (Mari et al., 2000; Liu et al., 2001; Barret et al., 2010). Substantial entrainment of mid-level air in the convective column reduces the fraction of boundary layer air contained in the upper tropospheric convective outflow. This result directly questions the classical calculation of convective enhancement factor only based on upper tropospheric and boundary layer mixing ratios.

It is worth noting that our findings are based on the simulation of a single case study with only one cloud-resolving model. Different flux and concentration values would be expected if different resolutions (vertical and horizontal) are used. For simulations with parameterized deep moist convection, the choice of the convection parameterization would also be of importance (Arteta et al., 2009; Tost et al., 2010).

The numerical strategy developped in this work will be applied to further interpretation of the impact of West African MCSs on atmospheric chemical composition in the framework of the AMMA program.

Acknowledgements. Computer time has been provided by the Institut du Développement et des Ressources en Informatique Scientifique (IDRIS) and Météo-France. This work was funded by the french API-AMMA program. Based on an French initiative, AMMA was built by an international scientific group and is currently funded by a large number of agencies, especially from France, the United Kingdom, the United States, and Africa. It has been the beneficiary of a major financial contribution from the European Community's Sixth Framework Research Programme. Detailed information on scientific coordination and funding is available on the AMMA International Web site at http://www. amma-international.org. MSG observations were obtained from SATMOS.

Topical Editor P. M. Ruti thanks two anonymous referees for their help in evaluating this paper.

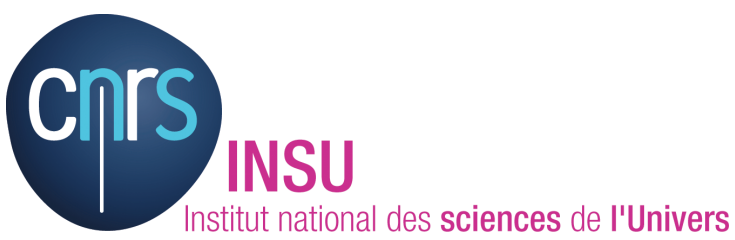

The publication of this article is financed by CNRS-INSU.

\section{References}

Aghedo, A. M., Schultz, M. G., and Rast, S.: The influence of African air pollution on regional and global tropospheric ozone, Atmos. Chem. Phys., 7, 1193-1212, doi:10.5194/acp-7-11932007, 2007.

Ancellet, G., Leclair de Bellevue, J., Mari, C., Nedelec, P., Kukui, A., Borbon, A., and Perros, P.: Effects of regional-scale and convective transports on tropospheric ozone chemistry revealed by aircraft observations during the wet season of the AMMA campaign, Atmos. Chem. Phys., 9, 383-411, doi:10.5194/acp-9-3832009, 2009. 
Arakawa, A.: The cumulus parameterization problem: Past, present and future, J. Climate, 17, 2493-2525, 2004.

Arteta, J., Marécal, V., and Rivière, E. D.: Regional modelling of tracer transport by tropical convection - Part 1: Sensitivity to convection parameterization, Atmos. Chem. Phys., 9, 70817100, doi:10.5194/acp-9-7081-2009, 2009.

Barnes, G. and Sieckman, K.: The environment of fast and slowmoving tropical mesoscale convective cloud lines, Mon. Weather Rev., 112, 1782-1794, 1984.

Barret, B., Ricaud, P., Mari, C., Attié, J.-L., Bousserez, N., Josse, B., Le Flochmoën, E., Livesey, N. J., Massart, S., Peuch, V.H., Piacentini, A., Sauvage, B., Thouret, V., and Cammas, J.P.: Transport pathways of $\mathrm{CO}$ in the African upper troposphere during the monsoon season: a study based upon the assimilation of spaceborne observations, Atmos. Chem. Phys., 8, 3231-3246, doi:10.5194/acp-8-3231-2008, 2008.

Barret, B., Williams, J. E., Bouarar, I., Yang, X., Josse, B., Law, K., Pham, M., Le Flochmoën, E., Liousse, C., Peuch, V. H., Carver, G. D., Pyle, J. A., Sauvage, B., van Velthoven, P., Schlager, H., Mari, C., and Cammas, J.-P.: Impact of West African Monsoon convective transport and lightning $\mathrm{NO}_{\mathrm{x}}$ production upon the upper tropospheric composition: a multi-model study, Atmos. Chem. Phys., 10, 5719-5738, doi:10.5194/acp-10-57192010, 2010.

Barth, M. C., Kim, S.-W., Wang, C., Pickering, K. E., Ott, L. E., Stenchikov, G., Leriche, M., Cautenet, S., Pinty, J.-P., Barthe, Ch., Mari, C., Helsdon, J. H., Farley, R. D., Fridlind, A. M., Ackerman, A. S., Spiridonov, V., and Telenta, B.: Cloud-scale model intercomparison of chemical constituent transport in deep convection, Atmos. Chem. Phys., 7, 4709-4731, doi:10.5194/acp-74709-2007, 2007.

Barthe, C. and Barth, M. C.: Evaluation of a new lightningproduced $\mathrm{NO}_{\mathrm{x}}$ parameterization for cloud resolving models and its associated uncertainties, Atmos. Chem. Phys., 8, 4691-4710, doi:10.5194/acp-8-4691-2008, 2008.

Barthe, C. and Pinty, J.-P.: Simulation of a supercellular storm using a three-dimensional mesoscale model with an explicit lightning flash scheme, J. Geophys. Res., 112, D06210, doi:10.1029/2006JD007484, 2007.

Barthe, C., Asencio, N., Lafore, J.-P., Chong, M., Campistron, B., and Cazenave, F.: Multi-scale analysis of the 25-27 July 2006 convective period over Niamey: Comparison between Doppler radar observations and cloud-resolving simulations, Q. J. Roy. Meteorol. Soc., 136(S1), 191-209, 2010.

Bechtold, P., Bazile, E., Guichard, F., Mascart, P., and Richard, E.: A mass-flux convection scheme for regional and global models, Q. J. Roy. Meteorol. Soc., 127, 869-886, 2001.

Berry, G. J. and Thorncroft, C.: Case study of an intense African Easterly Wave, Mon. Weaher Rev., 133, 752-766, 2005.

Bertram, T. H., Perring, A. E., Wooldridge, P. J., Crounse, J. D., Kwan, A. J., Wennberg, P. O., Scheuer, E., Dibb, J., Avery, M., Sachse, G., Vay, S. A., Crawford, J. H., McNaughton, C. S., Clarke, A., Pickering, K. E., Fuelberg, H., Huey, G., Blake, D. R., Singh, H. B., Hall, S. R., Shetter, R. E., Fried, A., Heikes, B. G., and Cohen, R. C.: Direct Measurements of the Convective Recycling of the Upper Troposphere, Science, 315, 816-820, 2007.

Borrmann, S., Kunkel, D., Weigel, R., Minikin, A., Deshler, T., Wilson, J. C., Curtius, J., Volk, C. M., Homan, C. D., Ulanovsky, A., Ravegnani, F., Viciani, S., Shur, G. N., Belyaev,
G. V., Law, K. S., and Cairo, F.: Aerosols in the tropical and subtropical UT/LS: in-situ measurements of submicron particle abundance and volatility, Atmos. Chem. Phys., 10, 5573-5592, doi:10.5194/acp-10-5573-2010, 2010.

Bougeault, P. and Lacarrère, P.: Parameterization of orographyinduced turbulence in a meso-beta model, Mon. Weather Rev., 117, 1872-1890, 1989.

Caniaux, G., Redelsperger, J.-L., and Lafore, J.-P.: A numerical study of the stratiform region of a fast-moving squall line. Part I: General description and water and heat budgets, J. Atmos. Sci., 51, 2046-2074, 1994.

Chaboureau, J. and Bechtold, P.: Statistical representation of clouds in a regional model, and the impact on the diurnal cycle of convection during TROCCINOX, J. Geophys. Res., 110, D17103, doi:10.1029/2004JD005645, 2005.

Chaboureau, J.-P., Cammas, J.-P., Mascart, P., Pinty, J.-P., Claud, C., Roca, R., and Morcrette, J.-J.: Evaluation of a cloud system life-cycle simulated by Meso-NH during FASTEX using METEOSAT radiances and TOVS-3I cloud retrievals, Q. J. Roy. Meteorol. Soc., 126, 1735-1750, 2000.

Chaboureau, J.-P., Cammas, J.-P., Mascart, P., Pinty, J.-P., and Lafore, J.-P.: Mesoscale cloud model scheme assessment using satellite observations, J. Geophys. Res., 107(D17), 4301, doi:10.1029/2001JD000714, 2002.

Chatfield, R. and Crutzen, P.: Sulfur dioxide in remote oceanic air: Cloud transport of reactive precursors, J. Geophys. Res., 89, 7111-7132, 1984.

Chauvin, F., Roehrig, R., and Lafore, J.-P.: Intraseasonal Variability of the Saharan Heat Low and Its Link with Midlatitudes, J. Climate, 23, 2544-2561, 2010.

Chong, M.: The 11 August 2006 squall-line system as observed from MIT Doppler radar during the AMMA SOP, Q. J. Roy. Meteorol. Soc., 136, 209-226, doi:10.1002/qj.466, 2010.

Chong, M., Amayenc, P., Scialom, G., and Testud, J.: A tropical squall line observed during the COPT81 experiment in West Africa. Part I: Kinematic structure inferred from dual-Doppler radar data, Mon. Weather Rev., 115, 670-694, 1987.

Cohan, D., Schultz, M., Jacob, D., Heikes, B., and Blake, D.: Convective injection and photochemical decay of peroxides in the tropical upper troposphere: Methyl iodide as a tracer of marine convection, J. Geophys. Res., 104, 5717-5724, 1999.

Collins, W., Stevenson, D., Johnson, C., and Derwent, R.: Role of convection in determining the budget of odd hydrogen in the upper troposphere, J. Geophys. Res., 104, 26927-26941, 1999.

Delon, C., Reeves, C. E., Stewart, D. J., Serça, D., Dupont, R., Mari, C., Chaboureau, J.-P., and Tulet, P.: Biogenic nitrogen oxide emissions from soils - impact on $\mathrm{NO}_{\mathrm{x}}$ and ozone over West Africa during AMMA (African Monsoon Multidisciplinary Experiment): modelling study, Atmos. Chem. Phys., 8, 2351-2363, doi:10.5194/acp-8-2351-2008, 2008.

Dickerson, R., Huffman, G., Luke, W., Nunnermacker, L., Pickering, K., Leslie, A., Lindsey, C., Slinn, W., Kelly, T., Daum, P., Delany, A., Grennberg, J., Zimmerman, P., Boatman, J., Ray, J., and Stedman, D.: Thunderstorms: An important mechanism in the transport of air pollutants, Science, 235, 460-465, 1987.

Doherty, R. M., Stevenson, D. S., Collins, W. J., and Sanderson, M. G.: Influence of convective transport on tropospheric ozone and its precursors in a chemistry-climate model, Atmos. Chem. Phys., 5, 3205-3218, doi:10.5194/acp-5-3205-2005, 2005. 
Gamache, J. and Houze, J. R. A.: Mesoscale air motions associated with a tropical squall line, Mon. Weather Rev., 110, 118-135, 1982.

Gettelman, A., Salby, M., and Sassi, F.: Distribution and influence of convection in the tropical tropopause region, J. Geophys. Res., 107, D10, doi:10.1029/2001JD001048, 2002.

Grant, D., Fuentes, J., Delonge, M., Chan, S., Joseph, E., Kucera, P., Ndiaye, S., and Gaye, A.: Ozone transport by mesoscale convective storms in western Senegal, Atmos. Environ., 42, 7104-7114, 2008.

Gregory, D., Morcrette, J.-J., Jakob, C., Beljaars, A. M., and Stockdale, T.: Revision of convection, radiation and cloud schemes in the ECMWF model, Q. J. Roy. Meteorol. Soc., 126, 1685-1710, 2000.

Guenther, A., Nicholas Hewitt, C., Erickson, D., Fall, R., Geron, C., Graedel, T., Harley, P., Klinger, L., Lerdau, M., Mckay, W. A., Pierce, T., Scholes, B., Steinbrecher, R., Tallamraju, R., Taylor, J., and Zimmerman, P.: A global model of natural volatile organic compound emissions, J. Geophys. Res., 100, 8873-8892, doi:10.1029/94JD02950, 1995.

Guichard, F., Asencio, N., Peugeot, C., Bock, O., Redelsperger, J. L., Cui, X., Garvert, M., Lamptey, B., Orlandi, E., Sander, J., Fierli, F., Gaertner, M. A., Jones, S. C., Lafore, J. P., Morse, A., Nuret, M., Boone, A., Balsamo, G., de Rosnay, P., Decharme, B., Harris, P., and Berges, J. C.: An Intercomparison of Simulated Rainfall and Evapotranspiration Associated with a Mesoscale Convective System over West Africa, Weather and Forecasting, 25, 37-60, doi:10.1175/2009WAF2222250.1, 2010.

Homan, C. D., Volk, C. M., Kuhn, A. C., Werner, A., Baehr, J., Viciani, S., Ulanovski, A., and Ravegnani, F.: Tracer measurements in the tropical tropopause layer during the AMMA/SCOUTO3 aircraft campaign, Atmos. Chem. Phys., 10, 3615-3627, doi:10.5194/acp-10-3615-2010, 2010.

Houze, R. A., Rutledge, S. A., Biggerstafff, M. I., and Smull, B. F.: Interpretation of Doppler weather-radar displays in midlatitude mesoscale convective systems, B. Am. Meteorol. Soc., 70, 613654, 1989.

Hu, X.-M., Fuentes, J. D., and Zhang, F.: Downward transport and modification of tropospheric ozone through moist convection, J. Atmos. Chem., 65, doi:10.1007/s10874-010-9179-5, 2010.

Jaeglé, L., Jacob, D., Wennberg, P., Spivakovsky, C., Hanisco, T., Lanzendorf, E., Hintsa, E., Fahey, D., Keim, E., Proffitt, M., Atlas, E., McElroy, T., Midwinter, C., Pfister, L., and Wilson, C.: Observations of $\mathrm{OH}$ and $\mathrm{HO} 2$ in the upper troposphere suggest a major source of convection, Geophys. Res. Lett., 24, 3181-3184, 1997.

Jaeglé, L., Martin, R. V., Chance, K., Steinberger, L., Kurosu, T. P., Jacob, D. J., Modi, A. I., Yoboué, V., Sigha-Nkamdjou, L., and Galy-Lacaux, C.: Satellite mapping of rain-induced nitric oxide emissions from soils, J. Geophys. Res., 109, D21310, doi:10.1029/2004JD004787, 2004.

Khaykin, S., Pommereau, J.-P., Korshunov, L., Yushkov, V., Nielsen, J., Larsen, N., Christensen, T., Garnier, A., Lukyanov, A., and Williams, E.: Hydration of the lower stratosphere by ice crystal geysers over land convective systems, Atmos. Chem. Phys., 9, 2275-2287, doi:10.5194/acp-9-2275-2009, 2009.

Lafore, J.-P. and Moncrieff, M. W.: A numerical investigation of the organization and interaction of the convective and stratiform regions of tropical squall lines, J. Atmos. Sci., 46, 521-544, 1989.
Lafore, J. P., Stein, J., Asencio, N., Bougeault, P., Ducrocq, V., Duron, J., Fischer, C., Héreil, P., Mascart, P., Masson, V., Pinty, J. P., Redelsperger, J. L., Richard, E., and Vilà-Guerau de Arellano, J.: The Meso-NH Atmospheric Simulation System. Part I: adiabatic formulation and control simulations, Ann. Geophys., 16, 90-109, doi:10.1007/s00585-997-0090-6, 1998.

Laing, A. G. and Fritsch, J. M.: Mesoscale Convective Complexes in Africa, Mon. Weather Rev., 121, 2254-2263, 1993.

Laing, A. G., Carbone, R., Levizzani, V., and Tuttle, J.: The propagation and diurnal cycles of deep convection in northern tropical Africa, Q. J. Roy. Meteorol. Soc., 134, 93-109, doi:10.1002/qj.194, 2008.

Lavaysse, C., Flamant, C., Janicot, S., Parker, D. J., Lafore, J. P., Sultan, B., and Pelon, J.: Seasonal evolution of the West African heat low: a climatological perspective, Clim. Dynam., 33, 313330, doi:10.1007/s00382-009-0553-4, 2009.

Lavaysse, C., Flamant, C., Janicot, S., and Knippertz, P.: Links between African easterly waves, midlatitude circulation and intraseasonal pulsations of the West African heat low, Q. J. Roy. Meteorol. Soc., 136, 141-158, doi:10.1002/qj.555, 2010.

Law, K. S., Fierli, F., Cairo, F., Schlager, H., Borrmann, S., Streibel, M., Real, E., Kunkel, D., Schiller, C., Ravegnani, F., Ulanovsky, A., D'Amato, F., Viciani, S., and Volk, C. M.: Air mass origins influencing TTL chemical composition over West Africa during 2006 summer monsoon, Atmos. Chem. Phys., 10, 10753-10770, doi:10.5194/acp-10-10753-2010, 2010.

Lawrence, M. G., von Kuhlmann, R., Salzmann, M., and Rasch, P. J.: The balance of effects of deep convective mixing on tropospheric ozone, Geophys. Res. Lett., 30, 1940, doi:10.1029/2003GL017644, 2003.

Lelieveld, J. and Crutzen, P.: Role of deep convection in the ozone budget of the troposphere, Science, 264, 1759-1761, 1994.

Liu, C., Moncrieff, M. W., and Grabowski, W. W.: Explicit and parameterized realizations of convective cloud systems in TOGACOARE, Mon. Weather Rev., 129, 1698-1703, 2001.

Lopez, J., Fridlind, A., Jost, H., Loewenstein, M., Ackerman, A., Campos, T., Weinstock, E., Sayres, D., Smith, J., Pittman, J., Hallar, A., Avallone, L., Davis, S., and Herman, R.: CO signatures in subtropical convective clouds and anvils during CRYSTAL-FACE: An analysis of convective transport and entrainment using observations and a cloud-resolving model, J. Geophys. Res., 111, D09305, doi:10.1029/2005JD006104, 2006.

Lu, R., Lin, C., Turco, R., and Arakawa, A.: Cumulus transport of chemical tracers 1) cloud-resolving simulations, J. Geophys. Res., 105, 10001-10021, 2000.

Mari, C., Jacob, D., and Bechtold, P.: Transport and scavenging of soluble gases in a deep convective cloud, J. Geophys. Res., 105, 22255-22263, 2000.

Mari, C., Saut, C., Jacob, D., Staudt, A., Avery, M., Brune, W., Faloona, I., Heikes, B., Sachse, G., Sandholm, S., Singh, H., and Tan, D.: On the relative role of convection, chemistry, and transport over the South Pacific Convergence Zone during PEM-Tropics B: A case study, J. Geophys. Res., 108, 8232, doi:10.1029/2001JD001466, 2003.

Mari, C., Reeves, C., Law, K., Ancellet, G., Andrés-Hernández, M., Barret, B., Bechara, J., Borbon, A., Bouarar, I., Cairo, F., Commane, R., Delon, C., Evans, M., Fierli, F., Floquet, C., Galy-Lacaux, C., Heard, D., Homan, C., Ingham, T., Larsen, N., Lewis, A., Liousse, C., Murphy, J., Orlandi, E., Oram, D., 
Saunois, M., Serça, D., Stewart, D., Stone, D., Thouret, V., van Velthoven, P., and Williams, J.: Atmospheric composition of West Africa: highlights from the AMMA international program, Atmos. Sci. Lett., 12, doi:10.1002/asl.289, 2010.

Masson, V.: A physically-based scheme for the urban energy balance in atmospheric models, Bound. Lay. Meteorol., 94, 357397, 2000.

McBride, J. L. and Gray, W. M.: Mass divergence in tropical weather systems. Part II: Large scale controls on convection, Q. J. Roy. Meteorol. Soc., 106, 517-538, 1979.

Minga, A., Thouret, V., Saunois, M., Delon, C., Serça, D., Mari, C., Sauvage, B., Mariscal, A., Leriche, M., and Cros, B.: What caused extreme ozone concentrations over Cotonou in December 2005?, Atmos. Chem. Phys., 10, 895-907, doi:10.5194/acp-10895-2010, 2010.

Mohr, K. I., Famiglietti, J. S., and Zipser, E. J.: The Contribution to Tropical Rainfall with respect to Convective System Type, Size, and Intensity Estimated from the $85-\mathrm{GHz}$ Ice-Scattering Signature, J. Appl. Meteor., 38, 596-606, 1999.

Mullendore, G. L., Durran, D. R., and Holton, J. R.: Crosstropopause tracer transport in midlatitude convection, J. Geophys. Res., 110, D06113, doi:10.1029/2004JD005059, 2005.

Neelin, J., Peters, O., Lin, J.-B., Hales, K., and Holloway, C.: Rethinking convective quasi-equilibrium: observational constraints for stochastic convective schemes in climate models, Phil. Trans. R. Soc. A, 366, 2579-2602, doi:10.1098/rsta.2008.0056, 2008.

Noilhan, J. and Planton, S.: A simple parameterization of land surface processes for meteorological models, Mon. Weather Rev., 117, 536-549, 1989.

Parker, M. and Johnson, R.: Structures and dynamics of quasi2D mesoscale convective systems, J. Atmos. Sci., 61, 545-567, 2004.

Parker, D. J., Burton, R. R., Diongue-Niang, A., Ellis, R. J., Felton, M., Taylor, C. M., Thorncroft, C. D., Bessemoulin, P., and Thompkins, A. M.: The diurnal cycle of the West African monsoon circulation, Q. J. Roy. Meteorol. Soc., 131, 2839-2860, 2005.

Pinty, J.-P. and Jabouille, P.: A mixed-phase cloud parameterization for use in mesoscale non hydrostatic model: simulations of a squall line and of orographic precipitations, paper presented at Conference of Cloud Physics, Everett, WA, USA, 1998.

Prather, M. and Jacob, D.: A persistent imbalance in HOx and NOx photochemistry of the upper troposphere driven by deep tropical convection, Geophys. Res. Lett., 24, 24, doi:10.1029/97GL03027, 1997.

Prospero, J. and Lamb, P.: African droughts and dust transport to the Caribbean: climate change implications, Science, 302, 10241026, 2003.

Randall, D., Khairoutdinov, M., Arakawa, A., and Grabowski, W.: Breaking the cloud-parameterization deadlock, B. Am. Meteorol. Soc., 84, 1547-1564, 2003.

Real, E., Orlandi, E., Law, K. S., Fierli, F., Josset, D., Cairo, F., Schlager, H., Borrmann, S., Kunkel, D., Volk, C. M., McQuaid, J. B., Stewart, D. J., Lee, J., Lewis, A. C., Hopkins, J. R., Ravegnani, F., Ulanovski, A., and Liousse, C.: Cross-hemispheric transport of central African biomass burning pollutants: implications for downwind ozone production, Atmos. Chem. Phys., 10, 3027-3046, doi:10.5194/acp-10-3027-2010, 2010.

Redelsperger, J.-L. and Lafore, J.-P.: A Three-Dimensional Simu- lation of a Tropical Squall Line: Convective Organization and Thermodynamic Vertical Transport, J. Atmos. Sci., 45, 13341356, 1988.

Redelsperger, J.-L., Diongue, A., Diedhiou, A., Ceron, J.-P., Diop, M., Gueremy, J.-F., and Lafore, J.-P.: Multi-scale description of a Sahelian synoptic weather system representative of the West African monsoon, Q. J. Roy. Meteorol. Soc., 128, 1229-1257, 2002.

Redelsperger, J.-L., Thorncroft, D., Diedhiou, A., Lebel, T., Parker, D., and Polcher, J.: African monsoon multiplidisciplinary analysis: An international research project and field campaign, B. Am. Meteorol. Soc., 87, 1739-1746, 2006.

Roux, F.: The West African squall line observed on 23 June during COPT81: Kinematics and thermodynamics of the convective region, J. Atmos. Sci., 45, 406-426, 1988.

Roux, F. and Sun, J.: Single-Doppler Observations of a West African Squall Line on 27-28 May 1981 during COPT 81: Kinematics, Thermodynamics and Water Budget, Mon. Weather Rev., 118, 1826-1854, 1990.

Roux, F., Testud, J., Payen, M., and Pinty, B.: West-African squall lines thermodynamic structure retrieved from dual-Doppler radar observations, J. Atmos. Sci., 41, 3104-3121, 1984.

Ruti, P., Williams, J., Hourdin, F., Guichard, F., Boone, A., vanVelthoven, P., Favot, F., Musat, I., Rumukkainen, M., Domingues, M., Gaertner, M., Lafore, J., Losada, T., de Fonseca, M. R., Polcher, J., Giorgi, F., Xue, Y., Bouarar, I., Law, K., Josse, B., Barret, B., Yang, X., Mari, C., and Traoré, A. K.: Modeling the West African climate system: systematic errors and future steps, Atmos. Sci. Lett., 12, 116-122, doi:10.1002/asl.305, 2011.

Saunders, R., Matricardi, M., Brunel, P., English, S., Bauer, P., O'Keeffe, U., Francis, P., and Rayer, P.: RTTOV-8 Science and validation report, Nwp saf rep., EUMETSAT, The Met Office, UK, 2005.

Saunois, M., Mari, C., Thouret, V., Cammas, J., Peyrillé, P., Lafore, J. P., Sauvage, B., Volz-Thomas, A., Nédélec, P., and Pinty, J. P.: An idealized two-dimensional approach to study the impact of the West African monsoon on the meridional gradient of tropospheric ozone, J. Geophys. Res., 113, D07306, doi:10.1029/2007JD008707, 2008.

Scala, J. R., Garstang, M., Tao, W. K., Pickering, K. E., Thompson, A. M., Simpson, J., Kirchhoff, V. W. J. H., Browell, E. V., Sachse, G. W., Torres, A. L., Gregory, G. L., Rasmussen, R. A., and Khalil, M. A. K.: Cloud draft structure and trace gas transport, J. Geophys. Res., 95, 17015-17030, 1990.

Schwendike, J., Kalthoff, N., and Kohler, M.: The impact of mesoscale convective systems on the surface and boundarylayer structure in West Africa: Case-studies from the AMMA campaign 2006, Q. J. Roy. Meteorol. Soc., 136, 566-582, doi:10.1002/qj.599, 2010.

Serça, D., Delmas, R., LeRoux, X., Parsons, D., Scholes, M., Abbadie, L., Lensi, R., Ronce, O., and Labrouc, L.: Comparison of nitrogen monoxide emissions from several African tropical ecosystems and influence of season and fire, Global Biogeochem. Cycle, 12, 637-651, 1998.

Thompson, A., Tao, W.-K., Pickering, K. E., Scala, J. R., and Simpson, J.: Tropical Deep Convection and Ozone Formation, B. Am. Meteorol. Soc., 78, 1043-1054, doi:10.1175/15200477(1997)078<1043:TDCAOF>2.0.CO;2, 1997. 
Tost, H., Jöckel, P., and Lelieveld, J.: Influence of different convection parameterisations in a GCM, Atmos. Chem. Phys., 6, 54755493, doi:10.5194/acp-6-5475-2006, 2006.

Tost, H., Lawrence, M. G., Brühl, C., Jöckel, P., The GABRIEL Team, and The SCOUT-O3-DARWIN/ACTIVE Team: Uncertainties in atmospheric chemistry modelling due to convection parameterisations and subsequent scavenging, Atmos. Chem. Phys., 10, 1931-1951, doi:10.5194/acp-10-1931-2010, 2010.

Tulet, P., Crahan-Kaku, K., Leriche, M., Aouizerats, B., and Crumeyrolle, S.: Mixing of dust aerosols into a mesoscale convective system: Generation, filtering and possible feedbacks on ice anvils, Atmos. Res., 96, 302-314, 2010.
Wang, Y. A., DeSilva, W., Goldenbaum, G. C., and Dickerson, R. R.: Nitric oxide production by simulated lightning : Dependance on current, energy and pressure, J. Geophys. Res., 103, 19149-19159, 1998.

Yasunaga, K., Kidan, H., Satomura, T., and Nishi, N.: A numerical study on the detrainment of tracers by cumulus convection in TOGA COARE, J. Meteorol. Soc. Japan, 82, 861-878, 2004.

Zipser, E. J.: Mesoscale and convective-scale downdrafts as distinc components of squall-line structure, Mon. Weather Rev., 105, 1568-1589, 1977. 